\title{
"Were not that a botchy core?": the Function of Disease in 2 Henry IV, King Lear, Troilus and Cressida, and Twelfth Night
}

By Catherine Joule

A thesis submitted to the Victoria University of Wellington in fulfilment of the requirements for the degree of

Master of Arts

Victoria University of Wellington

2015 


\section{Table of Contents}

$\begin{array}{ll}\text { Abstract } & 2\end{array}$

Acknowledgements

Introduction $\quad 4$

Elizabethan Disease and Medicine: An Incomplete Overview $\quad \mathbf{5}$

Acting: Disease, Life, and Character $\quad 10$

$\begin{array}{ll}\text { Sources } & 13\end{array}$

Chapter One: The Body Politic. 16

The Advisor-Physicians of Shakespeare's Political Bodies 23

Establishing the State's Body $\quad 27$

Disorder and the Spread of Disease within the Body Politic $\quad 31$

Rulers and the Health of the Body Politic 33

Chapter Two: Catching the Plague - The 'Nonnaturals', Disease, 47 and Social Disruption

Diet $\quad 48$

Exercise $\quad 59$

Miasma $\quad 62$

$\begin{array}{ll}\text { Sleep } & 64\end{array}$

$\begin{array}{ll}\text { Perturbation of the Mind } & 68\end{array}$

Chapter Three: Suffering - Mental Disturbance and Social Disorder 72

Madness in King Lear $\quad 73$

Madness in Twelfth Night $\quad 85$

$\begin{array}{ll}\text { Conclusion } & 97\end{array}$

$\begin{array}{ll}\text { Works Cited } & 99\end{array}$ 


\section{Abstract}

The social currency of disease has developed and changed dramatically over the centuries, and this thesis focuses on how Shakespeare used the currency of early modern disease in his plays. Shakespeare's use of disease and disease metaphors is discussed within the context of four plays: Henry IV Part Two, Twelfth Night, King Lear, and Troilus and Cressida. The first chapter (of three) finds that the purpose of disease within the body politic metaphors is, inevitably, complication. In order to counter and resolve the disease of the state, advisors become physicians, extending the potential of the analogy further until it permeates the social structure of the plays and our perception of the characters. Disease is employed to imply division, instability, and disorder within the imagined body of the state.

The second chapter shows how the idea of infection is used to highlight interpersonal concerns within the plays. The chapter uses references to early modern sources and beliefs about the four humours to illustrate how Shakespeare connects social disorder, disease, morality, and status. The discussion focuses on Galen's "nonnaturals" which were believed to affect humoral balance, highlighting the significance of early modern conceptions of diet, exercise, miasma, sleep, and stress which serve to create a pervading sense of disease in the social worlds of the plays.

The personal and often horrifying experiences of mental disease we are presented with in King Lear and Twelfth Night are the focus of the third and final chapter. The display of suffering is found to primarily serve to emphasise the commonality of man. In both plays (though at different levels of seriousness) insanity causes a loss of social status for the sufferer and, through this loss of status, their humanity is stressed. The dramatic potential of madness allows the theatre of the courtroom to be parodied to draw questions about injustice into the plays, though without offering any definitive conclusions to them. The literary nature of madness within these plays, furthermore, allows for the clear presentation of issues of class and justice. Generally Shakespeare abandons absolute realism in favour of using disease and disease metaphors as a disrupting influence on social and political order so as to emphasise a wide range of themes and ideas. 


\section{Acknowledgements}

I would like to take this opportunity to wholeheartedly thank my supervisors, Dr Geoff Miles and Dr Sarah Ross, who have provided a great deal of support for this thesis. Without their patience and knowledge this thesis would not have been possible. I would also like to thank Katie Magaña and Margie Michael who have made my time in the VUW English department endlessly interesting and enjoyable. I would also like to recognise the Victoria University of Wellington Library and English Department which have allowed me the space, access to materials, and unfailing encouragement to complete this research.

To all my friends and family who took the time to read and make comments on my work, let me discuss the weirder aspects of early modern medicine, and kept me from panicking about submitting, I am most grateful for your support.

Thank you. 


\section{Introduction}

Shakespeare wrote for the people of his time, people who lived in a world of fear, disease, and death. Unsurprisingly enough, fear, disease, and death frequently appear in his plays, and often play a pivotal part in shaping an audience's experience of the plays. My research poses the simple question: what is the function of disease in Shakespeare? I examine the ways in which disease is represented in Shakespeare's plays, and how it affects our interpretation of the social worlds which Shakespeare constructs. His presentations of society, characters, and themes of order and justice all have strong links to disease which I explore in four of Shakespeare's plays: The Second Part of Henry IV, Twelfth Night, Troilus and Cressida, and King Lear. My thesis is arranged in three parts. The first chapter of my thesis discusses the use of disease in political analogies of state and body, and the associations between this diseased imagery and civil disorder within the plays. The second chapter moves into investigating more social issues than issues of the state, and focuses on connections between contagion and interpersonal issues such as morality and class. The third and final chapter of the thesis focuses on how the presentation of a very literary individual suffering of disease serves to draw attention to social, class, and state issues.

The plays I have chosen are thought to have been written in the period 1598-1605, with two thought to be from the end of Elizabeth I's reign and two from James I's early reign. Three of these plays are from the three main genres of the time: a history, a tragedy, and a comedy, and the last - Troilus and Cressida - is a troubling amalgam of all three. The centrally focused date range of these plays - a range which includes the death of Queen Elizabeth I, the coronation of James I, and the height of Shakespeare's career - allows for some useful discussion of the literary use of disease while mitigating the risk of reaching too broadly into early modern history. These dates are, of course, open to debate and my choice has more to do with content than context. These four plays present and use disease through diverse means. For instance, at the beginning of Troilus and Cressida, Ulysses delivers an extensive speech which uses analogies of disease to comment on the disorder of the state, while Twelfth Night plays with the appearance of disease and social power as Malvolio is fooled into appearing mad. The main plot of 2 Henry $I V$ focuses upon the disease of a monarch, while the sub-plot is a riot of colourful disease and amorality. King Lear also focuses on the disease of a monarch, but less on the impact this has on the state and more on the personal experience and revelations of Lear. The wide variety of ways in which these 
plays present disease allows for a breadth of insight into the literary construction of human experience and mortality.

There are, of course, other plays of interest written in this period. Hamlet, for instance, is one of Shakespeare's most popular plays amongst both critics and audiences today. Yet, the play's almost obsessive focus on Hamlet himself does not lend it nearly so well to a discussion of social order as King Lear. Another potential play, with a strong focus on disease, was Measure for Measure. The unwavering prominence of venereal disease, however, does not add much to a discussion which already takes Troilus and Cressida and 2 Henry IV into account. As I hope to cover a range of diseases and social classes in my discussion, the four plays I have chosen to focus on provide a range of both, with room to make comparisons between them.

\section{Elizabethan Disease and Medicine: An Incomplete Overview ${ }^{1}$}

Before entering into a close discussion of Shakespeare's plays, we must establish some of the most significant aspects of a sixteenth-century understanding of disease. The early modern understanding of illness was rooted in a very different understanding of the body and, especially, the blood. The circulation of blood around the whole body was not understood before 1623, with blood believed to originate from the liver and be used up by the time it reached the fingers and toes (Hoeniger 147-8). ${ }^{2}$ This blood was believed to be comprised of four distinct substances called the four humours. This concept of the four humours was the fundamental medical principle derived from Galen and Hippocrates, and early modern people believed the body was both made from and fed by these humours.

The concept of the four humours is intimately related to the belief that all matter was comprised of four qualities: hot, cold, dry, and moist. The body was thought to be composed of four combinations of these qualities: blood, black bile, yellow bile, and phlegm otherwise known as blood, melancholy, choler, and phlegm (Bright A Treatise of Melancholy 5-7). Renaissance medicine focused on the humours as they existed in the blood, in which form

\footnotetext{
${ }^{1}$ It would be impossible to give a full, comprehensive, and detailed overview of Elizabethan medicine in the space of this thesis, let alone in just my introduction. For a detailed overview I recommend F. David Hoeniger's Medicine and Shakespeare in the English Renaissance, a work which lays out in great breadth and some detail the state of medical knowledge in Shakespeare's England; a work which laid the foundations for this thesis. ${ }^{2}$ The pulmonary circulation, the circulation of blood from the heart to the lungs in order to be oxygenated, was discovered in 1553 and 1559 by Servetus and Colombo respectively (Hoeniger 147). This was incorporated into Galenic belief that blood was refined by the lungs to feed the vital spirits of the body (the senses of sight and hearing etc.) (Hoeniger 145-6).
} 
they fed the organs. Each organ or part fed on certain humours according to its needs and in healthy individuals this would result in very little of the humours being left over, and all organs consuming enough to function. Unhealthy individuals were diagnosed as having either too much, or not enough, of a particular humour or pair of humours. Of the many means by which physicians and surgeons attempted to reinstate balance in the unhealthy body, diets, purges, and bloodletting were the most popular. Of these three, both bloodletting and purges were potentially deadly even without factoring in illness. However they imagined illness as occurring, the extremity of the remedies employed by early moderns is testament to the fear, pain, and death caused by diseases during the Renaissance.

While the theory of the four humours was widely known and accepted, the root cause of disease within this model was open to a certain amount of dispute. There tended to be lively debate on the matter between the religious and medical men. Men of the cloth regularly attributed the plague to divine punishment (Bartholomaeus Batman uppon Bartholome 62), and accusations that members of the Royal College of Physicians had atheist, pagan, or Catholic tendencies were common (Hoeniger 80). Medical men tended to exacerbate the issue, being largely unapologetic (or unconvincing in their apologies) about their religious practices or lack thereof (Clark 131). Their focus on the natural causes of disease also upset the clergy, as it tended to discount religious rhetoric. The difference of opinion concerning natural and spiritual causes of disease had been going on for centuries before the birth of Shakespeare, and there is evidence that most people were accustomed to the debate, F. David Hoeniger points out that "the medieval response was: for the soul, listen to the divines; for the body to Galen or Avicenna" (164). The religious turmoil of the Reformation, and the arrival of syphilis in about 1496-7, appears to have provoked a more moralistic view of disease, with Puritans especially eager to label the scourge of syphilis a punishment for wickedness (Fabricius 77-79). It is not my intent here to argue the possible distinctions between medieval and early modern perceptions of disease. Suffice to say, the view of disease as a punishment for sinful behaviour appears to have been a common coping mechanism. Attitudes of acceptance and accusation did nothing to further research into cures, or isolation of diseases such as syphilis. It is little wonder, then, that the more medically minded ignored theories of divine intervention, and instead followed ancient theories of contagion, such as those of miasma, and diet.

Influencing a person's balance of humours were what Gail Kern Paster refers to as Galen's "six nonnaturals" (Humoring the Body 4). These were activities, atmospheres, or attitudes which early moderns considered responsible for disrupting the humoral balance of 
the body and creating disease. These six were: perturbation of the mind, "air, diet, repletion and evacuation, sleeping and waking, and exercise" (Paster 4). Particularly fascinating is the theory that different kinds of air could cause imbalances or disease, and the links between this theory of miasma and the plague. In his A Treatise of the Plague, Thomas Lodge refers to Galen to describe the dangers of miasma:

Let us then conclude with Galen, in his Booke Of Treacle, to Piso, and Pamphilianus, that all pestilentiall sicknesses, as from the proper cause, are ingendred from the ayre, depraved and altered in his substance, by a certaine vicious mixture of corrupted and strange vapours, contrary to the life of man, and corrupting the vitall spirit: which unkindly excretion sowed in the ayre, and infecting the same, communicateth unto us by our continuall alteration of the same, the venome which poysoneth us. (Lodge 8)

The theory of miasma is the most impersonal of the non-natural explanations of disease, removing a great deal of both control and blame from the patient, making it an ideal explanation for the random distribution of plague victims. The theory of miasma originated in Galen's ancient Rome, which was built on a malarial swamp which caused a correlation between warm, rank air and disease and there is a certain logic in the theory, as there is a correlation between things smelling bad and causing illness. In Shakespeare, the mentions of foul and sweet smells take on further significance when one is conscious of the threat posed by the air itself. To say "rank Thersites" (Troilus and Cressida 1.3.72) is as much to say Thersites smells bad, which is to say he is diseased and, furthermore, that he is contagious. Not all literary uses of miasma theory are straightforward; "Sweet Pandarus" "Sweet Helen" and "Sweet Cressid" (Troilus and Cressida 1.1.82; 3.1.139; 3.2.129) are examples of Shakespeare complicating the word 'sweet' by playing on the notion of miasma, blame, and disease. This will be discussed in more detail in my discussion of the nonnaturals in the second chapter. ${ }^{3}$

Alongside the more irrational theories of the bloodletting and divine punishment are those which, like some of the non-natural theories, seem more logical from our modern standpoint. Syphilis and gonorrhoea were recognised as being sexually transmitted (which

\footnotetext{
${ }^{3}$ I do not discuss repletion and evacuation in this chapter as it would require a different set of plays, and more space to present a proper discussion of the subject.
} 
fed into the concept of divine punishment), and contact with the infected and their clothing was discouraged (Fabricius 124). Indeed, principles of quarantine were well understood, and leprosy is believed to have been eradicated in England by Shakespeare's day (though syphilis took its place to the extent that lazar houses were used to house and treat syphilitics) (Fabricius 72). In attempts to control the plague, quarantine efforts were put in place, though these did not restrict the movement of the flea ridden rats carrying the disease, or indeed the mass exodus from London during plague years which served to spread the disease across England. ${ }^{4}$

The fear of disease which lead to drastic quarantine methods being developed was well founded. Many diseases were essentially incurable during the sixteenth and seventeenth centuries. Syphilis, the bubonic plague, smallpox, and gout are just a few of the debilitating and deadly conditions which loomed over the average early modern Englishperson. When Falstaff rails, "A pox of this gout! - or a gout of this pox! - for the one or the other plays the rogue with my great toe" ( $2 H 4$ 1.2.224-5), he indicates another issue which was faced by those suffering from disease, the medical practitioners, and historians in latter times. Medicine of the sixteenth century had no means by which to distinguish between diseases. Development of diagnosis was hindered by both confusion between symptoms and the belief that someone could only be ill of one thing at a time (Fabricius 255). This belief informs Falstaff's outburst, and his confusion about which disease he has grants him leeway to continue his debauched lifestyle. In a similar fashion those who were infected with syphilis were believed to be safe from the plague. As to the confusion of symptoms, gonorrhoea was believed to be the early stage of a syphilitic infection, and this becomes pertinent in Shakespeare as the burning symptoms of one disease are used figuratively for both, as they were conceived to be a single disease (Fabricius 256). Therefore, to take an overly modern or diagnostic approach to Shakespeare's references to disease can be reductive. In mentioning burning, Shakespeare not only refers to the temporary symptoms of gonorrhoea, but also the lifelong debilitation of syphilis or the great pox.

The doctor, in Renaissance England, had little power against the diseases of his day. Physicians dealt with internal illness, balancing the humours through prescribing diets, regimen, and purging or bleeding (Hoeniger 1). Actual bloodletting was generally undertaken by surgeons who dealt with external issues or any procedures which required the dirtying of

\footnotetext{
${ }^{4}$ Elizabeth I's Orders, thought meete by Her Maiestie, and her Priuie Counsell to be executed throughout the counties of this realme, in such townes, villages, and other places, as are, or may be hereafter infected with the plague, for the stay of further increase of the same... 1593 is one such example of state-prescribed quarantine.
} 
hands (Hall "the epistle" tiiia). Apothecaries were responsible for the making and dispensing of medicines and there was frequent tension between the apothecaries and the physicians due to unlawful prescriptions and non-standardised mixing of medicines (Hoeniger 23). It was a matter of some contention that people chose to see the apothecary rather than the physician, a situation which is comparable to today's practice of asking a chemist for his opinion on minor medical issues rather than paying the cost of seeing a doctor. The three branches of Renaissance medicine, the physicians, surgeons, and apothecaries, were a thin fragmented line of defence against the horrors of disease in an age where medical 'fact' was based on texts over a thousand years old.

I have endeavoured to restrict my use of primary medical sources to what is strictly related to the plays. I by no means claim to give a complete picture of the state of medicine during Shakespeare's lifetime; indeed I have confined my arguments to what would most likely be understood by the greatest number of people. In doing so, it has become evident that, even if Shakespeare possessed specialised knowledge and training in medical science, he has avoided making use of such things in his plays. His work may be used as evidence for common knowledge of medical learning, but it does not give any sort of clear indication of the medical debates on the nature of disease at the time. I use the phrase common knowledge, but perhaps common experience would be more fitting. Medical debates in the form of treatises and books by physicians could only be deemed useful insofar as they agreed with one another, but the dietaries and books of remedies written for laypeople often proved more straightforward, and far more useful for this study. The diverse audiences Shakespeare wrote for did not all have specialised medical training, but they all would have experience with disease and simple medicine as laid out in the dietaries. It is this experience which Shakespeare taps into with his references to disease in his plays.

Medical books written for wide audiences, like the dietaries, not only plainly set out the basics of medical theory in such a way that the expected areas of familiarity are evident, but also prove to be interesting reading. An impression of everyday life in London may be gained in such booklets as Present remedies against the plague, which recommends:

IT is very convenient that you keep your houses, streetes, yardes, backesides, sincks, and kennels sweet and cleane from all standing puddeles, dunghils, and corrupt moystures which ingender stincking savoures that may bè noysome, or breed infection: nor suffer no doges to come running into your houses, neither keepe 
any (except it be backewarde, in some place of open aire) for then are very dangerous, and not sufferable in time of sickenesse, by reason they runne from place to place, and from one house to another, feeding uppon the uncleanest thinges that are cast forth in the streetes, and are a most apt cattell to take infection of any sicknesse, and then to bring it into the house.

(Learned phisition 3)

The idea of dogs running from place to place, around dunghills and rubbish piles, from house to house certainly adds colour and life to the idea of miasma, which the author is bringing to the fore in this section of the booklet. Elsewhere he urges the use of rosemary, bay leaves, and frankincense to engender beneficial smells to ward off the plague. Today it is well understood that the plague was spread primarily by fleas, so the exclusion of dogs was, retrospectively, good advice. Indeed a great deal of disease treatment and prevention at this time can be regarded as good practice, but bad science. Dunghills are bad for the health, and it is good to keep the place one is living clean to avoid disease, but it is not the smell itself which will cause the disease. In the case of Shakespeare's plays, bad science has become great literature; disease is no longer understood to function as early moderns understood it, but in the literary world of Shakespeare, diseases still manage to bring the plays to life.

\section{Acting: Disease, Life, and Character}

Disease constitutes an essential part of Shakespeare's work. Many of his great characters are defined by their place in an early modern conception of illness. I refer to Falstaff from the Henriad a great deal over the course of this thesis. He is engaging in multiple ways, and while he is perhaps the liveliest of Shakespeare's characters, he is also one of the most abundantly and enthusiastically diseased. From the plays of ancient Athens, theatre has relied upon stock characters for ease of recognition. Morality plays of medieval

England drew on these tendencies to produce plays which relied upon audiences recognising the Vice figure from the opening of the play. The audience may enjoy or deplore the Vice's behaviour, but the use of a stock character ensured it would be perceived as wrong. Disease rhetoric adds to these stock characters by both reinforcing the sinfulness of characters like Falstaff through metaphoric connections of sin and disorder to disease, and, at the same time, 
presenting a pathetic experience with which an audience can identify. These two functions of disease may seem contradictory, but by including disease at almost every level of his plays, Shakespeare invokes an undeniably human experience with which his audience could connect in both its literal and metaphoric states.

The role of the actors in conveying the play's diseases is not to be discounted. It is essential that in a performance of King Lear the audience sees a performance of madness, and likewise in a performance of Falstaff's role we see the havoc being played with his big toe. In reading the plays it is easy to reduce the presentation of disease to its vocalisation alone, and yet, within the lines, there are numerous indications of the visual nature of disease. When Doll Tearsheet's diseases are compared to jewellery, the terms of display are re-written as visual beauty and repugnancy are placed side by side. 'Rank' Thersites would suit being presented as visually diseased, supporting his verbally diseased presence in Troilus and Cressida. Recapturing the performances enjoyed by Shakespeare's audience in this respect is impossible. An awareness of the pervasive nature of disease in these plays, however, should be essential for actors and directors shaping a performance, as many characters are so irrefutably distinguished by their illnesses. The exact manner in which disease was visually represented in original performances may be lost to time, but that should not prevent actors today embracing the potential within the text for wearing disease as a costume for these characters.

Characters had, of course, been defined by disease theories before Shakespeare - a trend which was paralleled by a tendency to present people as characters. Theophrastus, a Greek philosopher, presented people in general as being classifiable into a number of essential character types in his On Moral Characters. These types were to be recognised by both appearance and behaviour, which in turn were rooted in their "Humours and Tempers" (2). Doubtless this text was influenced by theatre, and its clear portrayal of type and humour certainly added to the construction and use of stock characters in the centuries following. With the development and refinement of humoral theory over the course of the Middle Ages and Renaissance, stock characters became still more intricate.

Early modern dietaries, some of which I have already referred to, invariably outline the personalities connected to each of the eight possible humoral imbalances. ${ }^{5}$ To reassert the commonality of humoral knowledge is not my purpose here; instead I would like to point to the literary power of the theory. Even in this medically enlightened era it is simple to find

\footnotetext{
${ }^{5}$ The four humours could manifest in eight different personality types.
} 
personality tests which will place an individual in one of the eight categories, though today there is less emphasis placed on how one might change one's category. Early moderns believed that personality was malleable, and that a person naturally progressed through a variety of life stages. Jaques lists these in As You Like It as follows:

All the world's a stage,

And all the men and women merely players;

They have their exits and their entrances,

And one man in his time plays many parts,

His acts being seven ages. At first, the infant,

Mewling and puking in the nurse's arms.

Then the whining schoolboy, with his satchel

And shining morning face, creeping like snail

Unwillingly to school. And then the lover,

Sighing like furnace, with a woeful ballad

Made to his mistress' eyebrow. Then a soldier,

Full of strange oaths and bearded like the pard,

Jealous in honor, sudden and quick in quarrel,

Seeking the bubble reputation

Even in the cannon's mouth. And then the justice,

In fair round belly with good capon lined,

With eyes severe and beard of formal cut,

Full of wise saws and modern instances;

And so he plays his part. The sixth age shifts

Into the lean and slippered pantaloon,

With spectacles on nose and pouch on side;

His youthful hose, well saved, a world too wide

For his shrunk shank, and his big manly voice,

Turning again toward childish treble, pipes

And whistles in his sound. Last scene of all,

That ends this strange eventful history,

Is second childishness and mere oblivion,

Sans teeth, sans eyes, sans taste, sans everything. 
Here we can see the progress of one man through many stock characters, and simultaneously through his life. Shakespeare draws attention to the close connection between life and acting, with the actor potentially shifting his behaviour to follow the lines. As this happens Shakespeare strips from life its complexities while he adds them to his character, as Jaques demonstrates an awareness of mortality, past and future which appears natural in the light of the manufactured presentation of 'reality'. This epiphanic speech is not, however, applying play characters directly to life. Instead it connects with the early modern concept of humoural development and the process of aging as it was commonly set out at the time. The observations of the progress of life and the connections to the typical stage characters were already there for Shakespeare to draw on. Born of the philosophies of their time, Shakespeare's characters are intimately connected to medicine, medicine to life and life to the stage.

\section{Sources}

The connection between life, stage, and disease is now obscured by time. History presents us with another world, and tells us it is our own. What we can see of early modern perceptions of life can only be gleaned through texts which are often baffling in their assumptions. In Newton's The Touchstone of Complexions "Whorlehattinge" and "pitching the hare" are listed as exercises for strong men (53). No explanation is given as to what these activities might entail, nor have I been able to find one. Evidence is limited to what was written down and what early modern people believed needed to be preserved. Within the bounds of the evidence, assumptions about what Renaissance English believed personally must be made. In interpreting such evidence there is, of course, the risk of assuming too much. It is a far greater risk, however, to ignore the context in which Shakespeare's works were written. Knowing that disease was understood as a decline in the natural balance of the humours, and that the humours were believed to be intrinsically connected to personality and mood, King Lear becomes even greater as a tragedy of decline. When the reader understands the connections between the state and disease, otherwise baffling and dull speeches in the history plays become rich in meaning.

Some essential foundational work has already been done in this area of Shakespeare scholarship. One of the earliest significant scholars in the field was Sir. John Charles Bucknill 
who wrote The Medical Knowledge of Shakespeare, The Mad Folk of Shakespeare: Psychological Essays, and The Psychology of Shakespeare. As a medical professional his work offers an interesting perspective on the plays he discusses; however he does have a distinct tendency to diagnose characters as if they were living breathing humans rather than literary constructions. R. R. Simpson and Aubrey C. Kail, doctors and also authors of Shakespeare and Medicine and The Medical Mind of Shakespeare respectively, share Bucknill's focus on diagnosis within the plays. Simpson's work is the more useful of the two, though he tends to exaggerate the significance of Shakespeare's medical knowledge. Kail's tendency to use medical references in Shakespeare's work as evidence for medical practice of the time may be helpful for a historian, but does not advance the literary field beyond Simpson's work. Far more influential on my work is F. David Hoeniger's Medicine and Shakespeare in the English Renaissance which, despite somewhat limited discussion of Shakespeare, gives an excellently researched overview of the treatment of disease during Shakespeare's lifetime - one which stresses the accessibility of medical ideas at the time. Another excellent reference source for the early modern medicine references apparent in Shakespeare is Sujata Iyengar's Shakespeare's Medical Language: A Dictionary, which provides definitions for medical and disease terminology which appear in Shakespeare's works. Also of note, and in a more literary vein, is Gail Kern Paster's Humoring the Body: Emotions and the Shakespearean Stage which tackles the problem of the psychological materialism of early modern medicine and the significance of humoral passions in Shakespeare's plays.

Here, my focus is on the function of disease, and reference to disease, within just four plays. My chapters are arranged according to the relationship between disease and the characters of the play. In my first chapter I will discuss the significance of the body politic analogy, a political comparison of the state to a body which functioned in a wide range of discourse during the early modern period. Moving from concerns of nation and state to more interpersonal and community concerns of contagion, my second chapter discusses references to five of the six "nonnaturals" which were believed to affect humoral balance. I investigate how simple actions such as eating, sleeping, and breathing were closely connected to disease and thereby to concepts of corruption and immorality. My third and final chapter discusses the more personal experience of disease and suffering with which we are presented in these plays, and the connection between this literary suffering and early modern concern with social order and justice. 


\section{Chapter One: The Body Politic}

The body politic analogy (a comparison of a commonwealth to a physical body) was a hugely versatile means by which people discussed issues of state for centuries. Coriolanus contains one of the most memorable uses of the body politic analogy in all of Shakespeare's works. ${ }^{6}$ In the very first act of the play, in the first of the scenes set in Rome, a brewing riot is halted in its tracks by Menenius' use of body politic rhetoric. In an extended passage from 1.1.77 to 152 Menenius argues that Rome is like a body, which must be ruled by its stomach the Senate. In his fable all the members rebel against the stomach, accusing it of hoarding food. The stomach replies that, though it does initially receive the food, it is then responsible for distributing the viands throughout the whole of the body. Using this analogy Menenius concludes the riot unjust, as all benefits stem from the Senate against which the citizens rebel. He endeavours to use the analogy to condemn the actions of the citizens, but unfortunately the simple structure highlights the issue that has caused the riot: The citizens are not receiving food from the Senate.

This simple form of the body politic is derived from the foundational, and certainly the oldest, form of the analogy. The earliest preserved mention of the body politic appears in a collection attributed to Aesop. Called 'the fable of the belly' it tells the simple story of how the feet and the belly argued, the feet being disgruntled at having to carry the belly around. In reply the belly tells the feet they can only carry the belly due to the nutrients it provides. The moral in Aesop's version is given as "Great armies would mean nothing if the generals did not exercise good judgement" (Hale The Body Politic 26; translation by Lloyd W. Daly). This fable appears again in Plutarch's Life of Coriolanus where the analogy follows the line of Aesop's but is developed further, with more metaphorical connections employed to paint the picture. The moral is also elaborated, and applied to the structure of the state rather than the army. In Shakespeare's version, though, the analogy is not really updated beyond the imagery presented by Plutarch; he does not present a Renaissance version of the body politic, but rather a consciously classical one.

\footnotetext{
${ }^{6}$ Some notable discussions of this passage are can be found in James Emerson Phillips Jr.'s State in Shakespeare's Greek and Roman Plays and David George Hale's The Body Politic: A Political Metaphor in Renaissance English Literature. Hale's article "Coriolanus: The Death of a Political Metaphor" and Delphine Lemonnier-Texier's "The Analogy of the Body Politic in Shakespeare's Coriolanus: From the Organic Metaphor of Society to the Monstrous Body of the Multitude" also present worthwhile, and more focused, readings of Coriolanus' body politic.
} 
Shakespeare uses the archaic form of the body politic analogy here to construct a consciously archaic politic world. Shakespeare follows the basic structure of the story found in Plutarch, but the characters are continually drawing attention to the old-fashioned and nearly obsolete nature of this construction of a body politic (Hale "Coriolanus: The Death of A Political Metaphor" 198). Menenius introduces the tale as being "pretty" as in quaint or old fashioned, and suggests that it is stale. The First Citizen alludes to the early modern body politic in the lines:

$$
\text { Your belly's answer - what? }
$$

The kingly crownèd head, the vigilant eye,

The councellor heart, the arm our soldier,

Our steed the leg, the tongue our trumpeter,

With other muniments and petty helps

In this our fabric, if that they -

$$
(1.1 .103-8)
$$

However, he is cut off by Menenius and relegated to the role of "the great toe of this assembly" (1.1.144). A modern critic trapped in the heroic past, the First Citizen emphasises the anachronism of Menenius body politic, but is deprived of the power to undermine it. Such a play on the development of the body politic suggests a wide ranging familiarity with the analogy amongst Shakespeare's audience and, furthermore, a deep understanding, on Shakespeare's part, of the significance of the analogy to his society.

The concept of the interdependence of people within the state, upon which the analogy relies, is manipulated within the analogy of the body politic. Significance is given to each body part by the arguments of the speaker, and a section of society is connected to the part. Organs are generally given more consideration than arms and legs, perhaps because the workings of organs were more mysterious and connected, therefore, to the upper classes whose contributions to society could also be rather mysterious. In the Coriolanus passage, the Plebeians are relegated to legs (and one to the big toe). Coming to the 'moral of the story', Menenius explains:

The senators of Rome are this good belly, And you the mutinous members. For examine Their counsels and their cares, digest things rightly 
Touching the weal o' th' common, you shall find

No public benefit which you receive

But it proceeds or comes from them to you

And no way from yourselves.

The stomach rules the state of the body, just as the senate which controls the food guides the state. Note that, as Menenius implores the crowd to 'digest things rightly' he blurs the line between the senate and commons - Menenius is here asking the Plebeians to digest his words as a stomach does food. Even as Shakespeare mimics Plutarch for most of the fable, he complicates the possible interpretations and undermines any 'straight' reading of the passage. The anachronistic and unhealthy state presented in Coriolanus, ruled by a stomach which fails to feed the body, undermines the construction of a heroic past. Instead, the diseased state actively rejects the heroic and Coriolanus, as the concerns of the people are largely the concerns of the stomach. ${ }^{7}$ Unfortunately, Shakespeare's careful use of an outdated body politic analogy to accomplish this contrast between the petty squabbling of an old democracy and classical heroism is easily missed without some understanding of the development and importance of body politic analogies to Shakespeare's contemporary society.

In the plays I wish to focus on, the body politic does not fall into the ancient forms found in Menenius' tale. Instead, use of the analogy reflects the forms and complexity it had developed by Elizabeth I's reign. The development of the body politic analogy from Plutarch to the Renaissance was heavily influenced by Christianity, which complicates the secular image we see in Shakespeare's plays. St. Paul's description of the church as the Body of Christ came to be used extensively in Church propaganda in the early Church (Hale The Body Politic 29).

For as the body is one, and hath many members, and all the members of one body though they be many, yet are but one body, even so is Christe. For by one spirit are we all baptised into one

\footnotetext{
${ }^{7}$ Food remains a major concern of the plebeians, and is used as a justification for the peoples' change of face when voting on Coriolanus' consulship:

The people cry you mocked them, and of late

When corn was given them gratis, you repined,

Scandalled the suppliants for the people, called them

Time-pleasers, flatterers, foes to nobleness.

(Coriolanus3.1.44-48)
} 
body, whether we be Jewes or Gentils, whether we be bonde or free: and have all droncke of one spirit. For the body is not one member, but many. If the fote woulde say because I am not the hande, I am not of the body: is it therfore not of the body? And if the eare woulde say, I am not the eye, I am not of the body: is it therfore not of the body? If all the body were an eye, where were then the hearing? If all were hearing: where were the smellinge? But nowe hath God set the members every one severally in the body as it hath pleased him. For if they were all one member, where were the body? Nowe are there many members, yet but one body. And the eye can not saye unto the hande, I have no nede of thew: Nor, the heed againe to the fete, I have no nede of you. Yea rather a great deale those members of the body which seeme to be more feble, are necessary. And upon those members of the body whiche we thinke least honest, put we more honestye on. And oure uncomely partes have more comelyness on. For oure comely members neede it not: But God hath tempered the body together, and hath geven the more honour to that parte which lacked: leste there shoulde be any strife in the body: but that the members shoulde have the same care one for another. And if one member suffer, all suffer with him: if one member be had in honour, all members rejoice with it.

Ye are the body of Christe, and members one of another.

(1 Corinthians $12: 12-27)^{8}$

By positioning the Pope as the head of the church and emphasising both the importance of the head to the body and the placement of church authority as the soul of the body politic, the Church was able to re-interpret the original meaning of the passage to support their control over secular authorities. However, during the Middle Ages, especially after the rediscovery of Aristotle's Politics in 1280, secular authorities began to utilise body imagery as a form of state propaganda (Hale 38). ${ }^{9}$ Countering Church propaganda with their own, heads of state

\footnotetext{
${ }^{8}$ All Biblical references taken from: The Holie Bible. London, 1568. - an English translation of the Bible with which Shakespeare would have been familiar.

${ }^{9}$ Aristotle's work constructs a pre-Christian and largely secular political system.
} 
used the body image to argue for control over their own states and the ability to limit the power and interference of the Church. The Church, on the other hand, maintained power through arguing that it was the spirit or soul of the body politic. The nearly wholly secular view of the body politic present in Shakespeare is largely a consequence of the division of England from Rome, which resulted in the body politic moving into largely secular use (Harris Foreign Bodies 32). While Christianity was maintained to be the soul of social life, Catholic propaganda was to be avoided at all costs. As a result it is generally the secular leader or monarch who, in Shakespeare's plays, is described as a soul or spirit (see TC 1.3.55), if either is mentioned at all. It is this more complex and more secular body politic which is found in most of Shakespeare's work.

Both the structure of the state, and the state of medical learning, during the English Renaissance led to a widespread use and understanding of the body politic analogy at the time. Belief that order in the macrocosm mirrored order in the microcosm had led to a tendency to use the body to explain political order, but also for political order to be used to explain the body (Harris 19). Both the order of the body and the order of the state were believed to be divinely appointed, and both orders were guaranteed to be a part of individual experience of life. Everyone had a body, and everyone was a part of the nation. Use of the mirroring analogies in both medical and political discourse of the time picks up on this personal experience, and the human desire for order, to argue a range of points. The structure of one was almost invariably understood in terms of the structure of the other, which necessarily led to a near stagnation of ideas - the same arguments repeated over and over, using the same analogies as evidence. For literature of the age, the stagnation of the analogy and its arguments was not necessarily a bad thing, as it allowed for a wider dissemination and understanding of the arguments. In turn this allowed authors and playwrights to build and maintain problematic representations of states through subtle use of the analogy, or to overtly stress the impact of the individual on the wider state by politicising their individual bodies.

In Shakespeare's plays the body politic analogy is commonly used to illustrate political circumstances and social order but, as Shakespeare's plays reflect the world in which he lived, the body politic is also an integral part of how he structures his play-worlds. With the exception of the classical histories and Troilus and Cressida, in the majority of Shakespeare's plays, the state functions in a similar fashion to the way in which the sixteenthand seventeenth-century English state functioned. There are kings and princes, advisors and nobility, and, of course, the rabble. In these states, the health of the 'body politic' as a whole is theoretically reliant on the king or leader of the state, who is figured as either the head or 
the heart of the state. The monarch was an important symbol of nationhood - a rallying point and an indicator of ultimate order. By the sixteenth century, the secular body politic had become much more hierarchical and less mutually dependent - a form of the Body Politic which persisted throughout Shakespeare's lifetime. Harris describes this development writing:

\begin{abstract}
Whereas Saint Paul insists that "if one part is hurt, all parts are hurt with it" (12:26), a Stuart adaptation of this line characteristically reads "When a Kinge's head but akes, / Subjects should mourne." In this model, there is little or no reciprocity between "high" and "low" within the body; the lesser members owe their health (and in certain versions, their very existence) to the king, but not vice versa.
\end{abstract}

(Harris Foreign Bodies 33)

The dependence of the state upon the health of the king or queen was good propaganda, and it seems evident that playwrights frequently reinforced the idea in the public mind. John Webster opens his The Duchess of Malfi with the assertion that:

$$
\text { a Prince's court }
$$

Is like a common fountain, whence should flow

Pure silver-drops in general. But if't chance

Some curs'd example poison't near the head,

Death and diseases through the whole land spread.

$$
\text { (1.1.9-15 [italics original]) }
$$

This speech not only makes the connection between the prince and the head, it also makes a religious allusion through the fountain image, the fountain having a strong metaphorical association with Christ. ${ }^{10}$ The association with divinity here reflects a widespread concern with morality, church reformation, and the power of the monarch, which can be found throughout early modern literature. The corruption of this divine power is granted emphasis through the threat of unconfined disease and death. Furthermore, where the "curs'd example"

\footnotetext{
${ }^{10}$ The fountain metaphor was especially common in prayers; see the opening prayer of Batman uppon Bartholome at p1 for a good example of the association between divinity and fountains.
} 
is almost certainly administering a moral poison, the diseases which spread throughout the land are suggested to be more physical by their association with death. This imbalanced social rhetoric, where the immorality of the upper classes is purported to have physical and deadly consequences on the lower-classes, mystifies the established order and emphasises the consequences of change.

The use of disease imagery to create tension by corrupting the heavenly ideal social order was common even outside the heightened drama of play worlds. As political propaganda the body politic model maintained the passivity of the people largely by tapping into their fear of disease. Harris refers to "what Greenblatt regards as a larger pattern of Tudor authority's self-legitimation through the production and containment of subversion" (9). References to disease were widely used to create an atmosphere of uncertainty, of worry, and to encourage the people of the state to maintain the established order for fear of physical or moral affliction. The nature of the disease used in the imagery, however, tended to be nonspecific. Susan Sontg, writing about the metaphorical use of disease, argued that:

Traditional disease metaphors are principally a way of being vehement; they are, compared with the modern metaphors, relatively countless. Shakespeare does many variations on a standard form of the metaphor, an infection in the "body politic" making no distinction between a contagion, an infection, a sore, an abscess, an ulcer, and what we would call a tumour. For the purposes of invective, diseases are of only two types: the painful but curable, and the possibly fatal. Particular diseases figure as examples of diseases in general; no disease has its own distinctive logic. Disease imagery is used to express concern for social order, and health is something everyone is presumed to know about. Such metaphors do not project the modern idea of a specific master illness, in which what is at issue is health itself.

(Illness as a Metaphor 72)

The state of medical knowledge at the time is, of course, largely to blame for a lack of specificity in disease metaphor in the early modern era. It is far more important to look at what the references to disease do, than to seek to diagnose the ailment used in the metaphor. 
The creation and subsequent curing of diseases in Shakespeare's body politics has far more to do with reinforcing order than creating and maintaining a medically realistic image.

\section{The Advisor-Physicians of Shakespeare's Political Bodies}

Shakespeare usually establishes and draws attention to his use of the body politic trope through a set of very important figures: the advisor-physicians. Before going further into exploring the use of disease within Shakespeare's body politics, we must understand the position of the characters that most heavily rely upon the analogy in their rhetoric. In 1606 Barnabe Barnes, in his Four Books of Offices, establishes the duty of the councillor to the commonwealth thus:

for if this life (which I tearme to bee the forme of gouernment) bee sicke, or diseased, it is required, that the Counsellor should play the part of a wise Physition, by purgations, diets, vomites, bloudlettings, or other remedies, to medicine and rectifie the state of that bodie, where such policie laboureth.

(Barnes 42)

The drawing together of the roles of advisor and physician begins, then, with disease. Disease of the state, in Barnes' argument, demands a physician-like response from any good councillor. Political authors not only connected the role of the councillor to that of physician, they also made reference to medical practice to lend weight to their own arguments. In 1601 Gerrard De Malynes published A treatise of the Canker of England's Common wealh. Devided into three parts: Wherein the Author, imitating the rule of good Phisitions, First declareth the disease; Secondarily, sheweth the efficient cause thereof; Lastly, a remedy for the same. From the title of the work alone, it is evident that aligning an order of argument to the standard method of diagnosis was considered good rhetorical practice. Just like De Malynes, Ulysses takes on the rhetorical structure of the physician in order to lend his argument greater weight. Just as he borrowed many of his plots, Shakespeare borrowed the idea of the advisor-physician to provide an easily understood structure for his plays. 
Within Shakespeare's work many of his councillors are called upon to "play the part of a wise Physition" (Barnes 42). Ulysses in Troilus and Cressida, the Archbishop of York in 2 Henry IV, and Kent in King Lear all establish themselves as physician-like figures early in their plays. With the partial exception of the Archbishop, these characters are advisors to the state (the Archbishop arguably inhabits an advisory role within the counter-state); indeed in Henry IV part 2 Warwick, the king's advisor, also takes on the role of a literal physician to the king midway through the play. Being (largely) metaphorical physicians, these advisors diagnose the state and recommend remedies, and it is through their lines that we gain the clearest image of the diseased commonwealths Shakespeare constructs in these plays.

The most explicit connection between the role of advisor and that of physician comes in King Lear when Kent challenges Lear saying, "Do; / Kill thy physician, and the fee bestow / Upon thy foul disease" (1.1.163-5). He is here reacting to Lear's decision not only to divide his state and give over his responsibilities to his daughters but, furthermore, to exile his youngest daughter who loves him most. Given that the body politic only functions in the background of this play, which emphasises private suffering over state disorder, Kent's explicit use of this body politic role distinguishes him from the other characters. Kent is perhaps the only figure (with the possible exception of the Fool) who consistently adheres to the terms of the social contract the body politic represents, an attitude which serves only to complicate him further as an advisor-physician. ${ }^{11}$

The locating of the advisor figure as a doctor necessarily denies him a clear position within the body politic. Kent is unable to help Lear because Lear retains the power to banish him. Unheeded and exiled from his patient, he can do no good. Even when he takes on the name Caius and follows Lear as a servant he cannot cure Lear, as he is the only figure who continues to respect Lear's position as the king. ${ }^{12}$ Instead the exiled Cordelia returns, from the outside in, with her physician to cure both the state and Lear. Metaphorical disease having contaminated almost every aspect of the body politic of England we are presented with in Lear, only those who have been exiled from the commonwealth are in a position to aid the commonwealth. Kent's inability to help Lear, even after his exile, emphasises the extremity

\footnotetext{
${ }^{11}$ While one could argue that Gloucester continues to behave responsibly within the body politic, he is first responsible for the prominence of Edmund - a symptom of the disease consuming the body politic. Secondly, he is repeatedly separated from the king, as he attempts to follow the unnatural structure put in place by Lear, and follows two masters.

${ }^{12}$ John Caius (1510-1573) is a significant figure in Elizabethan medical history. He served as president of the Royal College of Physicians for a number of years, and as physician to the royal family. Clark's A History of the Royal College of Physicians of London: Volume One goes into more detail about Caius' impact on the history of medicine in London and England.
} 
of the decay of order we see in this play. In the dire circumstances we see in Shakespeare's tragedies, external checks are almost invariably needed to restore order.

Ulysses, the advisor-physician in Troilus and Cressida, is differentiated from the other figures by his wit which has him play the roles of both the doctor and a part of the metaphorical disease of the state. He diagnoses the Greek forces in an extended speech in which he pronounces that "the enterprise is sick" (1.3.103), clearly demonstrating his role as an advisor-physician. However, he then reinforces his diagnosis with the example of Patroclus' mockery, and in imitating Patroclus' mockery he parodies it; in providing an example of Agamemnon being mocked, he mocks Agamemnon. The disease of the state is imagined as stemming from division and a lack of respect, and Ulysses proves his wit by simultaneously presenting an image of this 'disease' to be condemned, whilst also encouraging the disrespect of the audience. Again this hypocrisy serves two purposes in that it emphasises the contagious potential of disdain, and complicates Ulysses' position as an advisor-physician. Functioning in a play in which the body politic is poorly lashed together from the start, Ulysses is not required to stand against a figure of absolute authority; his physic does not need to explicitly emerge from a source exterior to the body. In order to complicate his position Shakespeare has granted Ulysses an irreverent sense of humour which is somewhat at odds with his continued support of and regard for Agamemnon. While his authority is drawn from the recognition of his intellect and his mastery of rhetoric, his humour undermines his ability to function as an effective physician of the state.

By contrast the advisors in 2 Henry IV, the Archbishop of York and Warwick, have rather straightforward relationships with the state. The Archbishop is an advisor-physician external to the state. As one of the heads of the rebellion he does not fit the role of advisor to the king, but he is an intelligent critic of the state. He presents himself thus to the loyal forces:

Wherefore do I this? So the question stands.

Briefly, to this end: we are all diseased,

And with our surfeiting and wanton hours

Have brought ourselves into a burning fever,

And we must bleed for it - of which disease

Our late King Richard, being infected, died.

But, my most noble lord of Westmorland,

I take not on me here as a physician, 
Nor do I as an enemy of peace

Troop in the throngs of military men;

But rather show a while like fearful war

To diet rank minds, sick of happiness,

And purge th'obstructions which begin to stop

Our very veins of life. Hear me more plainly.

I have in equal balance justly weighed

What wrongs our arms may do, what wrongs we suffer,

And find our griefs heavier than our offenses.

$$
(2 H 44.1 .53-69)^{13}
$$

It may seem rather incompatible to propose that the Archbishop is a physician figure given his line "I take not on me here as a physician", but his rhetoric follows almost exactly the order of argument set out by De Malynes' A treatise of the canker of Englands common wealth Deuided into three parts: wherein the author imitating the rule of good phisitions, first, declareth the disease. Secondarily, sheweth the efficient cause thereof. Lastly, a remedy for the same. Rather, his protestation that he is not a physician relates to the greedy archetype of the doctor. He is telling Westmorland that he is not rebelling for personal gain nor "as an enemy of peace"; explaining that his intentions are sound. However, his close involvement with the rebellion - a symptom of the diseased state - complicates the Archbishop to the extent that he cannot survive the cure of the state. He succeeds in that the prince swears to undertake his suggested reforms, but he must be purged from the state himself.

Warwick, unlike the Archbishop of York, is presented as a socially acceptable advisor-physician in 2 Henry $I V$. In his relationship with King Henry IV we are presented with the allowed advisor, who is able to function from within the established power structure by the will of the king. It is in King Lear that we see this relationship fall apart as Lear no longer heeds his Kent. In Troilus and Cressida Ulysses is both detached from the body politic and disrespectful of the authority which Agamemnon should possess. Warwick on the other hand is an allowed advisor, but his power to heal the body politic is limited by his acceptance within the structure. While he endeavours to save both King Henry and the kingdom with his counsel he is limited by the extent to which he will be heeded. Unlike the Archbishop,

\footnotetext{
${ }^{13}$ Lines 55-77 are missing from $Q$, presumably due to the politically sensitive nature.
} 
Warwick is not in a position to force the issue and instead must rely on tact, as in this passage:

\author{
WARWICK Your majesty hath been this fortnight ill, \\ And these unseasoned hours perforce must add \\ Unto your sickness. \\ KING HENRY I will take your counsel. \\ And were these inward wars once out of hand, \\ We would, dear lords, unto the Holy Land.
}

(3.1.99-103)

Warwick cannot save King Henry - for all his advice he is not, after all, a physician proper and his place in the kingdom is threatened by the ascension of Hal. He mourns:

$\mathrm{O}$, that the living Harry had the temper

Of he the worst of these three gentlemen!

How many nobles then should hold their places,

That must strike sail to spirits of vile sort!

(2 Henry IV 5.2.15-18). ${ }^{14}$

The structure of the body politic is under the control of the king, not the advisor, in a healthy or diseased state. In all these examples the advisor/physician is ultimately proved incapable of curing the disease, only consoling the diseased.

\title{
Establishing the State's Body
}

It would be simple to assume that the body politic must first be firmly established within a play before the concept may be played upon. The body politic, however, had become intrinsic to the idea of the state by this time. It did not need to be referenced overtly for the audience to understand metaphorical implications delivered through reference to disease. In 2 Henry IV the first major speech on the body politic is delivered by the Archbishop of York in 1.3 , but the trope has been functioning earlier in the play. Northumberland's health is

\footnotetext{
${ }^{14}$ The "three gentlemen" referred to are Hal's brothers, who have just entered the scene.
} 
presented as a concern due to its repercussions on the body politic, and Hotspur's "spirit lent a fire / Even to the dullest peasant in his camp" (2 Henry IV 1.1.112-3). The death of Hotspur is linked to defeat at Shrewsbury through body politic concepts. The failure of the leader is connected to the failure of the whole army. Furthermore, the Archbishop's speech does not explain the structure of the body politic - it diagnoses it. On the other hand, in Troilus and Cressida the body politic is presented overtly, and its structure is spelled out, in the flattery of Agamemnon delivered by Ulysses in 1.3, which serves as an introduction to his lengthy speech on the body politic which follows. In these situations Shakespeare is manipulating the analogy in order to comment on the state; he does not waste time establishing the straightforward links between the state and the body, or establishing the order of the state as in the Coriolanus passage. Shakespeare is economical in his use of the body politic analogy, so when it does appear in lengthy passages it almost invariably provides valuable insight into the political circumstances of the play world.

Establishing the idea of the body politic is given a great deal of space early in both 2 Henry IV and Troilus and Cressida, which suggests the importance of the analogy to the themes of order and rule in both these plays. The first major speech on the body politic in 2 Henry IV serves to establish the position of the rebel forces. Lashing out at the monarch, who is perceived by the rebels as the cause for the body politic's disorder, and the commons, who originally enthroned Bolingbroke, the Archbishop of York uses the analogy to criticise both the rebellion and the state. ${ }^{15}$ The passage is as follows:

The commonwealth is sick of their own choice;

Their over-greedy love hath surfeited.

An habitation giddy and unsure

Hath he that buildeth on the vulgar heart.

O thou fond many, with what loud applause

Didst thou beat heaven with blessing Bolingbroke,

Before he was what thou wouldst have him be!

And being now trimmed in thine own desires,

Thou, beastly feeder, art so full of him

That thou provok'st thyself to cast him up.

\footnotetext{
${ }^{15}$ In a politically sensitive passage which did not appear in the first Quarto publication of the play, but does appear in QB and in the Folio. Scholars do agree that it was written by Shakespeare, but still debate whether it was a later addition or marked for excision on the original rough manuscript due to the politically sensitive nature of the lines.
} 
So, so, thou common dog, didst thou disgorge

Thy glutton bosom of the royal Richard;

And now thou wouldst eat thy dead vomit up,

And howl'st to find it.

It is immediately evident that this first extensive mention of the commonwealth as a body politic is not straightforward. There is some confusion concerning the use of the singular or plural in referring to the commonwealth ('is' and 'their' in the first line for example), and the body of the kingdom is not presented as that of a man but rather that of a dog. The commonwealth and the body politic were already blurred in literature of the time, which perhaps explains why Shakespeare oscillates between using the singular for an individual body of state or the plural to imply a gathering of people. Jean Talpin, in his A forme of Christian pollicie, defines "commonweales polleticke" as "Christians, who ought by nature, and are by grace all members conioyned and vnited in one boddy polliticke by Iesus Christ" (156). The idea of gathering all into one is the major concern of Ulysses in Troilus and Cressida, but the uncertain line between collective and individual statehood present in 2 Henry IV indicates a prevailing concern with the divided state.

To Shakespeare's audience, to invoke the commonwealth already implied a body politic image. The introduction of disease in the lines, "The commonwealth is sick of their own choice; / Their over-greedy love hath surfeited", firmly establishes Shakespeare's use of 'commonwealth' as interchangeably a reference to the body politic. Furthermore, it places the idea that the state is ill is at the forefront of the image, but also places the blame for the disease on the commonwealth.

Subverting expectations, it is not the illness of the monarch causing the sickness of the body politic, it is at the desire of the people that the state sickens. The degradation of this image into that of a beastly feeder makes it all the more powerful, as it draws in religious imagery and 'beheads' the state. The medicalised state and the unreasoning animal state are merged in the image of the dog who purges, but then is driven to eat the vomit. The strong connection between this image and the Biblical proverb "Like as the dogge turneth agayne to his owne vomite, even so a foole beginneth his foolishnes agayne afreshe" (Prov. 26:11) not only emphasises the speaker's position as Archbishop, it also reminds the audience of the repetition of rebellion across the Henriad plays. Displaced from the head of state to a foodstuff, the monarch is detached from this body politic and is not a part of its reasonless 
disorder. However, presenting kings as food is politically disruptive - suggesting not only that a monarch may be chosen, but also that they may be discarded at the whim of the body politic.

Presentation of a disordered body politic does not need to be subversive to have a dramatic impact. In contrast with the Archbishop's speech, Ulysses' speech from 1.3 of Troilus and Cressida emphasises divine order by applying disorder to the macrocosm. The speech opens with Ulysses outlining the divine order of the planets under the guidance of Sol, then asking:

But when the planets

In evil mixture to disorder wander,

What plagues and what portents, what mutiny?

What raging of the sea, shaking of earth?

Commotion in the winds, frights, changes, horrors

Divert and crack, rend and deracinate

The unity and married calm of states

Quite from their fixture. O when degree is shaked,

Which is the ladder to all high designs,

The enterprise is sick.

(1.3.94-103).

The motion of the planets was believed to be divinely ordered and to have real physical effects on the earth and the lives of men (Hoeniger 333-335; Clark 30). In this passage, though, the disordered planets make the entire earth sick. The raging, shaking, frights, changes, and horrors, can all be read as symptoms of a violent fever, a body in disorder. When the connection between the planets and sickness in the Renaissance mind is understood, the culmination of the passage with the line "The enterprise is sick" (1.3.103) has much greater weight to it. It is not the introduction of disease to the passage, it is the diagnosis, by the physician who intends to propose a cure.

The description of the upturned state which follows the moment of diagnosis takes on disturbing and animalistic qualities. In Ulysses' speech the issue is degree, and the declination of brain and heart, will and power, to the liver or appetite:

And appetite, an universal wolf, 
So doubly seconded with will and power

Must make perforce an universal prey,

And last eat up himself.

$(1.3 .121-24)$.

The 'wolf' which holds sway over head and heart threatens to devour the state. A 'wolf' is an animal, but in Shakespeare's time it was also used as a term for "certain malignant or erosive diseases" (OEDO "Wolf" 7a). In adding the discussion of appetite, Shakespeare opens the interpretation of the wolf as the liver, wolves commonly being associated with greed - appetite - at the time. There is a distinct similarity here between this wolf and the "beastly feeder" of Henry IV Part 2. The animalistic image emphasises an almost uncontrollable danger to the state, or rather the danger the state is to itself. The dog in the Archbishop of York's analogy provokes itself to vomit, while the wolf in Troilus and Cressida devours itself. The attribution of animalistic characteristics to the diseased state complicates our view of the political world within the play. Drawing on both the violence and greed associated with canine imagery, and the public concern and understanding invoked by reference to disease, the body politic metaphor is designed to be extremely effective at evoking concern about the political situation. Public concern is mingled with more immediate violent and unreasoning imagery of the "beastly feeder" or "universal wolf", disease standing for an almost inexpressible danger to the state.

\section{Disorder and the Spread of Disease within the Body Politic}

Interwoven with these concerns with devouring and bestial images is a concern with the infection and the spread of disease. The gap between an early modern understanding of infection and that which we have today can affect our interpretations of Shakespeare's body politic analogies. Modern readers interpret passages with an understanding of infection vastly different from that of the early modern audience. Today we understand that disease is caused by microbes, which are generally passed from one person to another via touch or through the air. In Shakespeare's time infection was not so well understood. Sexually transmitted diseases such as syphilis were understood to be reliant on contact, but these were often regarded as a punishment for fornication; even in this case, physicians had yet to pin down the microbe. Instead, infection was considered to have a great deal more to do with changes in the internal 
balance of the humours. Where we are inclined to see infection as the result of an alien assault, it is highly likely the early modern audience considered the 'infection' as the spread of disease from within the body of the state.

Infection within Shakespeare's body politics often follows the early modern tendency Harris notes, to have the disease of the body politic move from the top down. In Troilus and Cressida the concept is complicated by the power of opinion:

The great Achilles, whom opinion crowns

The sinew and the forehand of our host,

Having his ear full of his airy fame

Grows dainty of his worth

(Troilus and Cressida 1.3.142-145).

Disease emerges in this state due to the misplacement of regard, which causes a sort of corrupt power to be granted out of proportion to the wrong members. Achilles' ability to infect others is linked to the opinion of the masses who, granted power beyond their natural scope, crown him "With an imperial voice". Mass opinion, having been granted the power to confer a 'crown', is presented as disruptive and corrupting. The misplaced regard bestowed upon Achilles has caused rampant disease in the body politic, so that "tis this fever that keeps Troy on foot, / Not her own sinews." (1.3.135-6).

The clash between the divine right of Agamemnon to rule and the authority of public opinion granted to Achilles is emphasised by their duplicate positioning within the body politic. Ulysses names Agamemnon "nerve and bone of Greece" (1.1.54) early in the play ("nerve' meaning sinew), then Achilles is called "The sinew and forehand of our host" (143). The crowning of opinion is undoubtedly framed as a usurpation of right. This usurpation has an obviously negative effect on Achilles as he grows "dainty of his worth", and keeps to his tent acting out a sort of illness comparable to Malvolio's self-love. The diseased Achilles is, furthermore, infectious: the public who caused the disease then suffers from the same. The power of the masses in terms of granting a right to rule is recognised in a limited and wholly negative way; the idea of social contract as we understand it today is presented as chaotic, opening the state to disease.

The close relationship between disease and disorder in early modern medical theories encourages a broad reading of diseases within the body politic analogy. Shakespeare will often begin his analogies with large scale disorder and end with a diagnosis of disease. 
Ulysses' great speech on the state in 1.3 relies on this sort of argument. The speech begins with a discussion of the order of the heavens, then the earth. Even after his diagnosis that "the enterprise is sick", he continues to describe the issue, then point to the disease:

This chaos, when degree is suffocate,

Follows the choking.

And this neglection of degree it is

That by a pace goes backward in a purpose

It hath to climb. The general's disdained

By him one step below; he, by the next;

That next, by him beneath. So every step,

Exampled by the first pace that is sick

Of his superior, grows to an envious fever

Of pale bloodless emulation.

And 'tis this fever that keeps Troy on foot,

Not her own sinews. To end a tale of length:

Troy in our weakness lives, not in her strength.

$$
(1.3 .125-37)
$$

The description of the social disorder, which Ulysses believes to be at the heart of the Greek impotence, grows into a description of illness. The chaos itself which begins this passage is immediately associated with "suffocate" and "choking". The physical symptoms are used to emphasise the seriousness of the social disorder. Of further interest is the manner in which the body politic is separated out in this passage. It is the individuals on "every step" who grow sick of the "envious fever". In emphasising individual contraction, Ulysses draws further attention to the division within the Greek state making it clear that this division extends down every step of the social ladder. It is when this description of a divided and sick social order meets the singular "Troy" that the body politic analogy functions to its fullest in this chapter. Troy is described as a singular "her" while the Greeks remain an "our"; the unified body of the Trojan state is brought into direct confrontation with the ill and divided Greek state. Ulysses uses disease within this confrontation to make the impact which social disorder has had on the Greek state clear: "Troy in our weakness lives, not in her strength." 


\section{Rulers and the Health of the Body Politic}

The health of the body politic and the preservation of social order within the state are consistently presented as dependent on the 'health' of the leader. Rarely, however, does this have to do with purely physical disease. In Troilus and Cressida Thersites jokes that Agamemnon would be better "if he had boils, full, all over, generally" (2.1.2-3) because "Then there would come some matter from him" (2.1.8). The state's disease was clearly described in the preceding scene, so this jest serves to emphasise the source of the social problems. Agamemnon is not physically diseased, but is so lacking in sense in his rule that Thersites would see such a disease as an improvement. In imagining Agamemnon as diseased, it is made abundantly clear that he is the source of the state's disease; however, it is the lack of "matter" or statecraft which has caused the nation's illness, not a boil. Far more significant than physical debility is the emotional instability many of Shakespeare's kings and leaders display. The link between the humours and emotion meant that such instability or excess could be interpreted as either the symptom or the cause of disease. ${ }^{16}$ In 2 Henry IV Morton stresses the need for emotional control in a leader to Northumberland saying:

The lives of all your loving complices

Lean on your health, the which, if you give o'er

To stormy passion, must perforce decay.

$$
(1.1 .162-4)
$$

Here health is preserved by control of the emotions: humoral balance and emotions are, at least to an extent, under the control of the individual. However, the "complices", who are relying on Northumberland for their lives, have no control over the situation. Yet the health of Northumberland is positioned in the text as the deciding factor as to whether they live or die. Diseases may be to some extent staved off by the ruler, but the ruled are largely presented as being at the mercy of the diseased ruler, with no recourse to a higher law.

In defining the place of men in the commonwealth, Shakespeare's more political plays are greatly concerned with kingship and the place of the king in the body politic. One of the most pivotal instances of the ongoing discussion of kingship comes in at Act 3 Scene 1 of Henry IV Part Two. To place the passage in context: the King, unable to sleep, is found in

\footnotetext{
${ }^{16}$ I will go more into the relationship between emotional response and disease in the latter two chapters.
} 
disorder, wandering in his nightgown, a sure sign that something is amiss. Warwick, his advisor, enters and they discuss the state of the kingdom:

KING HENRY Have you read o'er the letter that I sent you?

WARWICK We have, my liege.

KING HENRY Then you perceive the body of our kingdom,

How foul it is, what rank diseases grow,

And with what danger near the heart of it.

WARWICK It is but as a body yet distempered,

Which to his former strength may be restored

With good advice and little medicine.

My lord Northumberland will soon be cooled.

(2H4 3.1.35-43)

Here the king bluntly introduces the body politic to the scene by making a direct reference to "the body of our kingdom". Shakespeare appears to be ensuring the turn from the private survey of the kingdom in the soliloquy, to the public discussion of the state is clear. This speech by Henry is not the first use of the body politic image, nor the first reference to the state's disease. That is established much earlier in 1.3 with the Archbishop of York's "The commonwealth is sick of their own choice" (1.3.87) speech. The significance of this exchange instead lies in how it establishes "what danger" is near the heart of the body politic. Shakespeare has built up the idea of the diseased state from the fringes in, from the rebel camp and the toes of Falstaff, and from Act Three he pulls this disease inwards through the body politic into the very body of the king.

The body of the kingdom we are confronted with in this passage is "foul", a veritable garden for "rank diseases" (the garden is used elsewhere as a metaphor for the body in the play and, to an extent, the state). The most obvious disease is the rebellion, which is the explicit subject discussed by the characters. The insurrection, in the opinion of King Henry, is a danger to the heart of the state - we might assume that Henry is referring to himself here, and many productions will have Henry gesture to his own heart in delivering this line. Of course by highlighting the heart as threatened, we have the suggestion of a mortal sickness and the death of the monarch as the death of the state itself. It is quite a pleasing way to bring the king's terminal illness to the fore before the scenes of collapse later in the play. In terms of Henry's fate then, Warwick's reply is not quite so comforting. The kingdom is "but as a 
body yet distempered, / Which to his former strength may be restored", but in comfortingly adjusting the dire message of the king's metaphor, he unwittingly undermines the importance of Henry to the narrative of the kingdom. The heart does not feature and, indeed is destined to be replaced.

Making the comforting troubling is something this play does very well, the best example being the rejection of Falstaff, wherein the comfort given by Warwick to the king in 4.3 is proven true. But the comfort of a wise and just new ruler is tempered with the discomfort we feel at his cold rejection of his companion Falstaff. In terms of our passage a similar sentiment may be found when Warwick advocates "good advice and little medicine. / My lord Northumberland will soon be cooled". ${ }^{17}$ Medicine fits with the cooling of tempers well. Medicine might cool the disease of the body politic - Northumberland. Cooling his hot head, he will not rebel. But more troubling is the connection between this cooling and the play on words earlier in 1.1 when Northumberland asks "Said he young Harry Percy's spur was cold? / Of Hotspur, 'Coldspur'?” (1.1.49-50). The familial connection between cooling and death is clearly established, and further supported by Northumberland's recovery “enraged by grief", heat being further connected to health. Warwick's line, then, may suggest that to cure the body politic Northumberland must (or more accurately "will") die.

Historically the Earl died in 1408 at the battle of Braham Moor, which marked the end of the Percy Rebellion. News of this is given in 4.3, prompting Henry's question, “And wherefore should these good news make me sick?'(4.3.102). The body politic is cured, but the king is not.

And so we must circle back to the line "And with what danger near the heart of it". As I have already noted, this makes for an aesthetically pleasing movement of disease through the body politic within the play, and it seems the cure (a purge in the darkest sense) follows almost the same path - though Falstaff takes until the next play to succumb. The body politic analogy generally places the king as either the head of state or the heart. The dispute between them resides in the contradiction between Aristotle's claim that the heart is the primary organ and Galen's that it is the brain. Shakespeare has chosen to use the heart here, not because of medical arguments, but because it provides a greater sense of centrality. That being said, there are certainly some similarities between the structure we are presented with here and that of the advisors in Troilus and Cressida.

\footnotetext{
${ }^{17}$ Note that the Folio colon perhaps better fits than the Norton full-stop, as the last sentence is not completely divorced from the meaning of the earlier lines.
} 
Less explicit in terms of the body politic is the depiction of rule in King Lear. The play may be seen as a condemnation of Lear's choices, but it is also a criticism of his humoral balance and ability to rule. Lear's choler is easy to note in the opening scene despite the reduction of the word's meaning in today's English. Indeed, the Renaissance idea of choler as one of the four humours informs the construction of Lear's character and the tragedy as a whole. Lear's decision to "shake all cares and business from our age" (1.1.37) is often deemed the folly of old age. However, when Lear flies into a rage over Cordelia's honesty, his disproportionate rage and inability to look to the consequences of his actions become more obvious. His behaviour is comparable to that of Hotspur in 1 Henry IV, who consistently pre-empts meanings and rashly jumps into unwise action. The circumstances in this play are wildly different. Whereas it is his father's and King Henry's responsibility to curb Hotspur as son and peer of the realm, no one, beyond God, has any power over Lear when the play begins. When Kent moves to curb Lear, he knowingly risks death. When Lear makes to draw his sword (adding drama as the frailty of age and the power of rage mingle), Kent tells him:

Do;

Kill thy physician, and the fee bestow

Upon thy foul disease. Revoke thy doom;

Or, whilst I can vent clamour from my throat,

I'll tell thee thou dost evil.

What exactly is meant by "foul disease" is open to interpretation. It could be Lear's imbalance of choler, his age, or his two elder daughters. The richest reading is achieved when all three possibilities are noted. It is interesting that advising upon matters of health and on matters of state are so close together in the mind of Shakespeare that the one almost always draws in the other. Even though the body politic is not explicitly mentioned in King Lear the principles of the image continue to function.

On the other side of the coin (as it were), we have the Trojan council in Troilus and Cressida. Theoretically Priam is presiding over the debate; however, his disconnection from state affairs is obvious if the rules of the body politic are observed. Priam does not speak for either side of the discussion, and allows Hector to take the reins of government. The excessive passivity of Priam is even more notable when compared to Lear's aggressively 
active rule in act 1 of King Lear. Age was reputed to sap away the heat of the body, and Priam's passivity fits far more with early modern conceptions of extreme age than Lear's choler. Lear's choleric old age leads him to symbolically behead and actively dissect his state. By contrast, in Troilus and Cressida the passivity of Priam emphasises the inactive position of besieged Troy, while also allowing Hector and the princes to take on the role of symbolic heads of state.

Whilst rule amongst the Trojans is becoming disjointed as the princes fall into a sort of oligarchical state structure, the Greeks are attempting to refocus rule onto one individual. Early in the play Agamemnon is placed into the role of king of the more troubled body politic in the play. Ulysses flatters him saying:

\author{
Agamemnon, \\ Thou great commander, nerve and bone of Greece, \\ Heart of our numbers, soul and only spirit \\ In whom the tempers and the minds of all \\ Should be shut up, hear what Ulysses speaks.
}

$(1.3 .53-7)$

Here we have an image of the body politic, and the position of Agamemnon, designed to emphasise the illness of the state through contrast. The idea of Agamemnon's neglected status is, of course, the basis of the discussion in 1.3. In Ulysses words "The specialty of rule hath been neglected" (1.3.77). The king lacks the respect of those who are meant to follow him, and the state is disordered. Here, in these speeches, which appose order to disorder, we find the idea of disease at the fore. The scene opens with Agamemnon asking "Princes, what grief hath set the jaundice on your cheeks?" (1.3.1), and he answers the rhetorical question with the assumption that it is the drawn out siege which so sickens them. Agamemnon attributes the downcast expressions of his companions to the "[c]hecks and disasters" which "[g]row in the veins of actions highest reared" (1.3.4-5). And yet, while the rest of the opening speech attributes the trials of the Greek army to the gods, trials to separate the grain from the chaff as the imagery goes, these lines foreshadow the reasons which are to be made clear later in the scene. It is unnatural 'growths' within the veins of the Greek camp, namely Achilles and Ajax, who delay the taking of Troy.

Agamemnon opens the scene with the idea of sickness, Nestor's speech which follows grants knees to oaks and ribs to ships, so the progression to the body politic analogy in 
Ulysses' speech is unsurprising. Shakespeare's use of the trope, however, is calculated. To begin with: Agamemnon is first figured as "nerve and bone of Greece," (TC 1.3.53). Nerve and bone are structural, not organs to which higher members of state are compared, placing emphasis on his position as a soldier and leader of soldiers. 'Nerve' of course has a pleasing double meaning, since it also means courage, which emphasises the flattering tone as Ulysses goes on in the next line to figure Agamemnon as "[h]eart of our numbers, soul and only spirit". 'Heart' and 'spirit' also suggest courage, continuing the punning, while this central line centres Agamemnon.

Indeed, it is the artistry evident in the structuring of the analogy which is both striking and important to the establishment of Agamemnon's position in the play. The "Heart of our numbers", which is so pleasingly centred between the physical and spiritual comparisons, is a relatively common comparison to make. But it is this framing of the common comparison which moves the analogy into new ground. The heart was believed to be responsible for converting regular blood to vital spirit and, in the words of Timothy Bright, "scattering the spirit of life throughout" (Bright 66). Thus the heart stands in an intermediate position between the bones and nerves which make up the body and the spirit and soul which possess it. In the case of Agamemnon, Shakespeare uses the heart to place the king in the middle ground between the logic and schemes of Nestor and Ulysses, and the base lusts and hungers of Ajax and Achilles. The centrality of the image of the heart in this context suits the play well. The Greek camp is formed of princes and Agamemnon is barely more than an equal in state, hemmed in by his own men. We come to an image of a king as besieged as Troy.

It is the manipulation of the body politic analogy, medical language, and disease which facilitates the variety we find in these plays. In Ulysses' praise of Agamemnon we encounter a figure who is not simply the heart of the state, but the whole body of the state. The entire commonwealth is metaphorically crammed into one person, who is in turn expanded into a sort of colossus. Agamemnon is "nerve and bone of Greece", imagined as a flesh-and-bone avatar of an entire geographical area. The Comedy of Errors contains a passage in which a maid is compared to a globe, and different countries are found out by their qualities and the qualities of the maid's features. By comparison with this explicitly geographical passage, it is evident that Shakespeare is far more politically concerned in the case of Agamemnon. Greece does lend the metaphor an impression of scope, but more importantly it creates a basic link between the Greeks as a whole and Agamemnon.

However, as in the case of King Henry IV, it becomes evident that the bond between the individual and the role, and the individual and the commonwealth, is a tenuous one. 
Agamemnon is imagined as a massive physical representation of the body politic, but then the image is undermined. Ulysses claims Agamemnon is one "In whom the tempers and minds of all / Should be shut up" (1.3.56-7). The figure depicted as large enough to encompass all of Greece is revealed as empty in one word; a 'should' instead of an 'are' is sufficient to bring the colossus crumbling down.

The image of one man as a body politic in and of himself is all the more interesting for the fact that it is almost always presented as a flawed or diseased body. The second half of Falstaff's "defence of sack" creates a similar sort of reversed body politic. The body is turned into a kingdom as Falstaff praises the qualities of sack:

it illuminateth the face, which, as a beacon, gives warning to all the rest of this little kingdom, man, to arm; and then the vital commoners and inland petty spirits muster me all to their captain, the heart; who, great and puffed up with his retinue, doth any deed of courage. And this valour comes of sherry.

(2H4 4.2.96-101)

The 'disease' of cowardice is cured by the application of alcohol; however, Falstaff's character is such that the disease is easily recognised as an excuse for the cure. Indeed Falstaff's behaviour throughout the play suggests there is not wine enough in the world to cure his cowardice. The inversion of the body politic - imagining the body as an army - is apt criticism of the circumstance in which the soliloquy is given. The young prince John has duped the rebel army, which is in flight, and an enemy knight has surrendered to Falstaff of all people.

As happens in Ulysses' flattery, the body politic presented in Falstaff's speech is divorced from the actual action of the play. The romantic idea of an army rallying to its captain is not present in the action of the conflict. Indeed Falstaff himself has failed to rally in a timely fashion, appearing only when the battle is clearly won. However, the mockery is indirect. While Falstaff clearly criticises Prince John in the wider passage, there is nothing to suggest Falstaff intends this to be a stab against his highness. Rather it seems to be more evidential of Falstaff's "manner of wrenching the true cause the false way" (2.1.101); his blithe disregard for factual evidence in favour of a good story. His accidental criticism of the state is, then, more humorous than pointed. Our only glimpse of the implied slaughter of the 
rebels comes through this scene and the lens of a triumphant Falstaff. Capped with this humorous speech on sherry, we are almost reassured about the health of the body politic.

The structure of the state Falstaff imagines is worth discussing. Benjamin Bertram, in "Falstaff's Body, the Body Politic, and the Body of Trade", suggests that Falstaff imagines a world "in which the restrictions of vocation and class position have vanished" (301), but I would argue he maintains the idea of class position but attempts personally to step beyond it. In his little kingdom of man he identifies with the heart, traditional rival to the prominence of the head, not with the petty spirits. He endeavours to usurp roles, not destroy them, seizing a sort of kingship within the plays by playing Hal's surrogate father. In 1 Henry IV he mockplays the king, and here in 2 Henry IV when angry at Prince John's cold distain, he delivers the passage:
Hereof it comes that Prince Harry is valiant; for the cold blood he did naturally inherit of his father he hath, like lean, sterile, and bare land, manured, husbanded, and tilled, with excellent endeavour of drinking good, and good store of fertile sherry, that he is become very hot and valiant. If I had a thousand sons, the first human principle I would teach them should be to forswear thin potations, and to addict themselves to sack.

(2H4 4.2.104-111)

This passage may play on widespread concern with blood, monarchy, and inheritance at the end of Elizabeth's reign. Raising the question of blood and humoral health so shortly after discussing a body politic suggests Falstaff is politicising blood. These questions are partially addressed by Catherine Belling. In discussing The Rape of Lucrece and Titus Andronicus, she makes connections between the contamination of an individual and the contamination of the state. She argues there is a "sense in which blood was a literally continuous link between individual human bodies and public states or hereditary bloodlines" (Belling 123). Falstaff's positive view of Hal's blood is tempered by the repeated fears of contamination expressed by King Henry IV. However, by placing emphasis on the similarity between Hal's blood and his own in opposition to that of Prince John, Falstaff recreates himself as father by blood to the future king and, in turn, the heart of the nation.

Falstaff tends to use the body politic metaphor to allude to his own, unprecedented potential for social mobility, and to connect this mobility to his decadent lifestyle. Bertram 
argues the symbolic order of the play is based upon the prohibition of pleasure, that pleasure is the disease (or disorder) of the body politic, and Falstaff's imagining of order within his sherry-corrupted body thus becomes parodic (Bertram 305). The heroic, in his opinion, must necessarily be divorced from the commonplace. However, in a play as concerned with the body politic as this one, the commonplace becomes an integral part of the nation, and forms a commonwealth capable of disgorging its king and the heroic itself. The play is less concerned with censuring pleasure, and more with negotiating the bounds of commonality, Falstaff progressively reveals his excesses, his vices, his debaucheries, over the course of the play. As his vices build up he becomes out of proportion and a figure we can no longer identify with. Belling tells us, "when individual phlebotomy overlaps with curative measures applied to the body politic, only some bodies continue to function as microcosms of the social macrocosm; others come to be identified as expendable or excremental" (Belling 127). The transition from a part of the state to a disease of the state is evident in the case of Falstaff. Becoming 'other' in both excess and distinction (his honours curtail the threat of the Lord Justice) Falstaff may be regarded as a disease of the body politic in a manner impossible in 1 Henry IV. The censure of pleasure is necessary to the symbolic order of the play, but it is only truly prohibited in excess. Hal yet remembers "the poor creature small beer" (2.2.10).

Shakespeare uses the "little kingdom" image to raise the political significance of metaphorically diseased figures to the point where they can be seen to threaten the state. Achilles maintains his position as a central concern of the Greeks by challenging Agamemnon in the ability to encompass a metaphorical kingdom. Ulysses diagnoses him as sick of self-love:

\section{Imagined worth}

Holds in his blood such swoll'n and hot discourse

That 'twixt his mental and his active parts

Kingdomed Achilles in commotion rages

And batters 'gainst himself.

The incorporation of the body politic provides a contrasting image to the harmonious kingdom of man Falstaff presents. Ulysses presents a war between mind and matter being waged within Achilles which directly correlates with the action of the play. The microcosm of an individual's disease is used to illustrate the disorder of the macrocosmic 
commonwealth. Falstaff's speech has essentially worked towards a similar end in that while he presents his body and mind as being in harmony, the audience has enough experience of his character to see through his words to the truth beyond. His mind may be willing but his complaint to Doll, "I am old, I am old" (2.4.243), is consistent with his impotence in action. Achilles is not nearly so apologetic about his lassitude, but his importance to the body politic is consistently stressed by the other characters.

The curing of disease within the body politic is integral to the resolution of Shakespeare's politically focused plays. 2 Henry IV has a strong and consistent focus on the fate of the diseased state. While the rebellion is symptomatic of disease within the existing state, both King Henry IV and Falstaff obsess over Hal's future reign. Within the play his behaviour is read as a potential danger to the state. The focus on the 'trickle down' system present within early modern conceptions of the body politic is used to create an artificial tension. The behaviour of Hal is used as evidence of disease, and this is given more than passing significance as the entire kingdom is presented as vulnerable to moral disease once he is crowned. When King Henry is told Hal dines in London with his usual company he exclaims:

For when his headstrong riot hath no curb,

When rage and hot blood are his councillors,

When means and lavish manners meet together,

$\mathrm{O}$, with what wings shall his affections fly

Towards fronting peril and opposed decay?

It is lack of control and unbalanced humours which the old king fears will bring decay to Hal and to England as a whole. The disease of the ruler, usually in the metaphorical sense, was perceived to cause disease across the entire realm. While Henry IV is undoubtedly physically ill, he is more concerned about Hal's perceived moral illness infecting the realm than his own.

While these fears fester in the king, we are also given the image of Henry IV succumbing to literal illness. Shortly after his outburst about the moral health of his firstborn son, upon hearing the news of the rebel army's defeat, the king collapses.

I should rejoice now at this happy news, 
And now my sight fails, and my brain is giddy.

O me! Come near me now; I am much ill.

The effects of the king's illness are widely felt. Gloucester notes that the people are frightened "for they do observe / Unfathered heirs and loathly births of nature" (4.3.121-2). The seasons and tides are also behaving erratically, and Clarence says, the old people, "time's doting chronicles, / Say it did so a little time before / That our great grandsire Edward sicked and died" (4.3.126-8). These omens and portents reflect the early modern belief in mystical forces, while adding to the drama of the play. Likewise in Julius Caesar the death of the general is foreshadowed by dire signs. The audience is not left to wonder what the meaning of these signs is. Gloucester soon thereafter states, "This apoplexy will certain be his end" (4.3.130).

Ending a play with the death of a king is, quite simply, good drama. The implications of such an act for a body politic vary. In Edmund Plowden's Commentaries or Reports we have record of a debate between several justices who, early in the reign of Elizabeth I, discuss the legal position of the king with reference to his position in the body politic. They use the analogy to describe what happens politically and legally when a king dies:

The king has two Capacities, for he has two Bodies, the one whereof is a Body natural, consisting of natural Members as every other Man has, and in this he is subject to Passions and Death as other Men are; the other is a Body politic, and the Members thereof are his Subjects, and he and his Subjects together compose the Corporation, as Southcote said, and he is incorporated with them, and they with him, and he is the Head, and they are the Members, and he has the sole Government of them; and this Body is not subject to passions as the other is, nor to Death, for as to this Body the King never dies, and his natural Death is not called in our Law (as Harper said), the Death of the King, but the Demise of the King, not signifying by the Word (Demise) that the Body politic of the King is dead, but that there is a Separation of the two Bodies, and that the Body politic is transferred and conveyed over from the Body natural now dead, or now removed from the Dignity royal, to another Body natural. So that it signifies a 
Removal of the Body politic of the King of this Realm from one Body natural to another.

(Plowden Reports 233a quoted in Kantorowicz The King's Two Bodies 13)

The authority and power of kingship is linked to the body of the state, which takes the form here of a mystical second body inhabited by the king. After the death of a king at the end of a play, Shakespeare almost always presents this movement of the king's body politic to another individual. In Troilus and Cressida Hector, who is arguably the head of the Trojan state, is killed by the Myrmidons and Achilles declares “So, Ilium, fall thou. Now, Troy, sink down. / Here lies thy heart, thy sinews, and thy bone.” (5.9.11-12). Given that the rhetoric of the body politic has presented characters as metaphorical representatives of the state as a whole - the body politic as a person - this could be interpreted as a surrogate victory, if not for the final speech delivered by Troilus, which indicates he has taken on the responsibility of head to the Trojan body politic. The replacement of the head of state is almost required to end a Shakespearean play, but in this case it does not conclude the play or cure the state of its diseases. Instead, Troilus and Cressida ends with a stalemate. Achilles has lost Patroclus, and Troy Hector, but Shakespeare retains that sense of continuing war and disorder by refusing to resolve the larger issues of heroism and social order he presents us with.

The lack of resolution in Troilus and Cressida is part of what places it firmly into the category of 'problem play'; the majority of Shakespeare's 'unproblematic' plays tend to end with a curing of the state's diseases. In 2 Henry $I V$ the threat of imminent disease, predicted by King Henry IV, is eradicated by Hal when he ascends the throne. He reassures the Lord Chief Justice that there is no grudge against him, then uses the analogy of the body politic to reassure generally that his governance is not one to be characterised by disease.

Now call we our high court of Parliament,

And let us choose such limbs of noble counsel

That the great body of our state may go

In equal rank with the best-governed nation;

The ponderous language Hal adopts as King Henry V emphasises his transition from the prince of the tavern to divinely ordained ruler. The shock is - of course - largely confined to 
the stage and, even then, Warwick has been an advocate for the prince throughout. So, while we may term it a dramatic rise to respectability, it is expected. The emphasis for the audience then, is not so much on Hal's change, but on the return of the body politic to good health. The "limbs" of state are to be noble, contrasting with Falstaff's complaints about his legs in the early acts. Furthermore the body of state is to go in "equal rank with the best-governed nation", presuming a parallel rise of the state with the rise of Hal to kingship. The ascension of Hal to the throne marks the end of the state's old diseases, and the rejection of Falstaff is a symbolic return of the nation to health.

The body politic analogies which help form the political worlds in these plays are almost never as straightforward as the analogy presented in Coriolanus. The purpose of disease within these metaphorical structures is, inevitably, complication. The form the disease takes is less important than the disruption it causes to the figure of the state. Division, instability, and disorder within the states are all brought to life through the use of disease and medical rhetoric within the body politic analogy. In order to counter and resolve the disease of the state, advisors become physicians, extending the potential of the analogy further until it permeates the structure of the plays and our perception of the characters. To pretend that Shakespeare's use of this analogy is revolutionary would be wrong. It was one of the primary ways in which early modern people thought about their states and, while Shakespeare is masterful in his use and complication of the diseased body politics he constructs, he is building on an early modern way of thinking. Similarly when constructing the diseased social worlds in these plays, Shakespeare is building on a way of seeing the world and disease. 


\section{Chapter Two: Catching the Plague - The 'Nonnaturals', Disease, and Social Disruption}

Within Shakespeare's plays disease serves more than just a political function; playing a part in both interpersonal relations and the more personal construction of character, the spreading and catching of illness functions primarily as a means of spreading themes of commerce, class, and morality through the play worlds. As noted earlier, early modern conceptions of contagion differ significantly from our modern understanding of infection and mutation. The theory of the four humours lay at the heart of the early modern understanding of disease and, furthermore, at the heart of contagion theory. Put simply, imbalance of the humours was believed, by most physicians, to be the ultimate source of disease in the body. Complicating this are the connections drawn by religious authorities between morality and disease, which, in many of Shakespeare's plays, serve to complicate our interpretation of diseased characters. Even within medical and Galenic constructions of humoral disease there is poetic leeway. Minor imbalance of the humours was considered inevitable and strongly linked to temperament, there being no clear division between psychology and physiology. Major imbalance or even a rapid shift away from one's natural temperament caused disease of the body or mind.

There were believed to be several major aspects of 'diet' which could affect the balance of humours in the body. The Touchstone of Complexions list them as follows:

For the Humours of the body, receiue and take sondry qualityes accordinge to the faculties that be in our nourishmente, and in the order of our vsual diet. Wherunto are to be added, Bathes, Heate, Exercise, Cold, Wearynes, Thyrst, Hunger, Sleepe, Rest, the state of [the] Ayre, and affections of the mynde: all which do sondry wayes, alter the habite and state of our bodyes, \& for the most part, maketh them worse.

(Newton Touchstone 29)

Early modern medical theory instructed practitioners to take note of a patient's regime as it would be the primary source of disease and, well adjusted, could prove the best means to a 
cure. Shakespeare's references to eating, revels, miasma, sleep, and worry use the language of disease to create thematic discussions of morality, commerce, and social order.

\section{Diet}

The ease by which one could become diseased by diet or habit is stressed in most dietaries dated to Shakespeare's period. In his A Treatise of Melancholy from 1586, Timothie Bright claims, "The causes of excesse of this humour are diuerse, and all (except it be receaued from the parent) spring from fault of diet ... this matter is increased by perturbation of mind, by temper of aire, and kind of habitation" (26). Bright recommends a change in diet, avoiding melancholy foods: "for your more speedie recouerie auoide them, and with choice of better, alter that which is amisse into a more cheerfull qualitie" (26-7). Onstage eating cannot, however, be regarded as solely medical; it was an important part of the theatre experience for customers, and Shakespeare's references to eating may appeal to the audience immediately as much as to a more metaphorical understanding of the world. Archaeologists at the site of the Rose Theatre, with the aid of botanists, have been able to compile a rather long list of common foodstuffs eaten at theatres in the sixteenth century alone. Neil MacGregor summarises:

Nuts were popular, and lots of fruit, dried and fresh: grape, fig, elderberry, plum, pear and cherry. A large amount of shellfish was also eaten: mussels, periwinkles, whelks, even a cuttlefish has been dug up. Oyster shells in particular have been found on the site in large numbers.

(Shakespeare’s Restless World 38).

Food was also probably eaten onstage, at various feasts (including during the final scenes of Titus Andronicus), and during revels such as those which appear in Troilus and Cressida and Twelfth Night. Nonetheless the connections drawn in the text between food and health, and health and morality help to build up meaning in some of Shakespeare's more riotous scenes.

Alehouse and tavern scenes of feasting in Shakespeare's work often associate imbalanced eating with a sense of moral corruption. Corruption and disease are nearly interchangeable, and often indistinguishable in the plays. This is largely due to moral 
corruption and physical corruption of the body existing in the same area of thought and philosophy in medieval and Renaissance medicine. The lack of division between psychology and physiology, and the importance of religion to the people, meant that discussions of morality were easily, and often, attached to Galenic theory. Thomas Newton's The Touchstone of Complexions is a good example of this mind-set. The extended title informs the reader that this work will not only show how the humours affect the body outwardly but also the inclinations, affections, motions, \& desires of his mynd inwardly. Corruption of the humoural balance, then, promises to cause not only the body but also the moral order of the man to fall into decline; the impossibility of perfect humoral balance is thus linked to original sin. Therefore, when in The Touchstone of Complexions there appears a chapter on such theoretical perfection, in introducing the chapter Newton is careful to point out that there is not "any such to be shewed in the whole world" (33). He provides a description of the perfect man only that the shortcomings of the other complexions may be understood, and so he might attribute such perfection to Christ. The pinnacle of perfection, then, is "A body [that] is in eche respect perfect \& sound, may most aptly be termed \& called Polycletlabus Rule" (Newton 34). ${ }^{18}$ However, perfection is pronounced a myth by Newton, "unlesse peradventure, as a man should say, that God speciallye and originallye had priviledged some suche from heaven" (33). A certain degree of imperfection and vice is, therefore, almost inevitably built into the traits of a character based on an early modern understanding of the body

While the endlessly corruptible nature of man may link back to the macrocosm of the state in the diseases of the body politic, Shakespeare is careful to show it in the microcosms of the individual characters as well. The connection between vice, disease, and food is clearly apparent in Measure for Measure, wherein Lucio tells the First Gentleman "thy bones are hollow, impiety has made a feast of thee" (1.2.50-1) in the course of witty banter, and Pompey offhandedly explains Mistress Overdone's circumstance by saying "she hath eaten up all her beef, and she is herself in the tub" (3.1.308-9). Disease, in this play, is centred upon the alehouse and Mistress Overdone, though vice is rampant regardless of setting. The same grotesqueness can also be found in 2 Henry IV. Falstaff, describing Bardolf, says, "his face is Lucifer's privy kitchen, where he doth nothing but roast malt-worms" (2.4.303-4), the burst veins of an alcoholic linked to both damnation and food preparation. In many respects, these

\footnotetext{
${ }^{18} \mathrm{He}$ is referring here to the rules of symmetry and proportion necessary for human beauty or perfection set down by ancient Greek sculptor Polykleitos in his Kanon. The Doryphorus sculpture supposedly illustrates these rules.
} 
connections are a reflection of Shakespeare's reality. Johannes Fabricius, in Syphilis in Shakespeare's England, investigating the spread of syphilis, argues that alehouses were not only common scenes of prostitution, but also significant disseminating centres for syphilis (103). Given that alehouses, taverns, and inns served food and drink and provided diseased prostitutes, it makes sense that there would be a strong connection between the tavern experience, disease, and moral decrepitude.

The strong connection between immoral behaviour and alehouses contributes to the 'Vice' characteristics of Falstaff. However, whereas in morality plays the Vice is intended to tempt the everyman figure of the hero into immorality, in 2 Henry IV this does not occur. While the threat Falstaff poses to Hal's humoral balance forms the basis of a great deal of dramatic tension within the play, Hal, the hero of the play, prince, and companion to Falstaff, is consistently represented as impervious to temptations. His character seems to be insurmountably virtuous. King Henry IV describes Hal as:

gracious, if he be observed;

He hath a tear for pity, and a hand

Open as day for melting charity.

Yet notwithstanding, being incensed, he is flint.

Newton says of the perfectly balanced man, "hee maye well serve for a notable paterne of vertue (that is to say) a most absolute perfection of nature in every point" (35). However, Newton also stresses that only Christ would be capable of such perfection. Hal is being deliberately presented as a Christ-like figure (Farrell 161), with not only the capacity to cure the state, but to also rule a golden age like Christ in the end days. While the allusion to Christ is not so dominant as to overwhelm the play in Christian imagery, it is crucial to our interpretation of the rejection of Falstaff and the curing of the state at the end of the play.

The strong connection between disease and vice, health and virtue, the health of the king and that of the nation, complicates how Hal's morality and his relationship with Falstaff are perceived within the play and by the audience. It is the near constant concern of the King that his son has been corrupted by the company of Falstaff and Poins. When he hears word that Hal has forsaken his brother's company in favour of dining in London with Poins, he laments: 
The blood weeps from my heart when I do shape

In forms imaginary th'unguided days

And rotten times that you shall look upon

When I am sleeping with my ancestors;

For when his headstrong riot hath no curb,

When rage and hot blood are his councellors,

When means and lavish manners meet together,

$\mathrm{O}$, with what wings shall his affections fly

Towards fronting peril and opposed decay?

Lines 63-4 both give 'when' clauses which obviously refer back to the two earlier plays Richard II and 1 Henry IV. Hotspur was certainly counselled by "rage and hot blood" while the downfall of Richard II was strongly suggested to be his "lavish manners". The first 'when' clause in line 62 may well be intended to refer to the revolt, which has just been quashed in this play. This is more difficult to say for sure that the phrase "headstrong riot" refers to the behaviour of the commonwealth as, unlike the other instances, the rebellion does not have a strong central figure. Certainly, though, King Henry is basing his fears for Hal on the humoral imbalances of his past enemies and their examples of misrule.

Even while creating tension based on Hal's relationship with the diseased Falstaff Shakespeare reassures his audience that these fears are ultimately ill founded. Warwick tells the king that, "The Prince but studies his companions" (2 Henry IV 4.3.68), and though he is scoffed at by the king, his argument undermines the dramatic tension created by the suggestion of moral disease. Nonetheless, a great deal of tension and drama in the final scenes is tied to Henry IV's concern about his legacy as he dies. Henry IV's concern creates the foundation for the crown scene's poignancy; however, Shakespeare has taken pains to undermine the audience's concern. To the audience Hal is presented as ultimately incorruptible. In creating this image of Hal, Shakespeare builds towards Henry V and his heroic reign, rather than complicating his youth any further. So while Hal may joke that "Belike then my appetite was not princely got; for by my troth, I do now remember the poor creature small beer" (2.2.9-10), he remains princely and heroic by his avoidance of vice or disease, despite the constant temptation of Falstaff.

Falstaff's eating and drinking to excess, not only threatens the future of the English state by threatening Hal, it also presents as a symptom of the disease of the current state. Of 
course, the two major diseases with which he is connected - gout and pox - were believed to be signs of immorality. Pox, or syphilis as we know it today, was linked to lust and alehouse whores like Doll Tearsheet, while gout was believed to result from gluttony. These beliefs are referred to in the exchange:

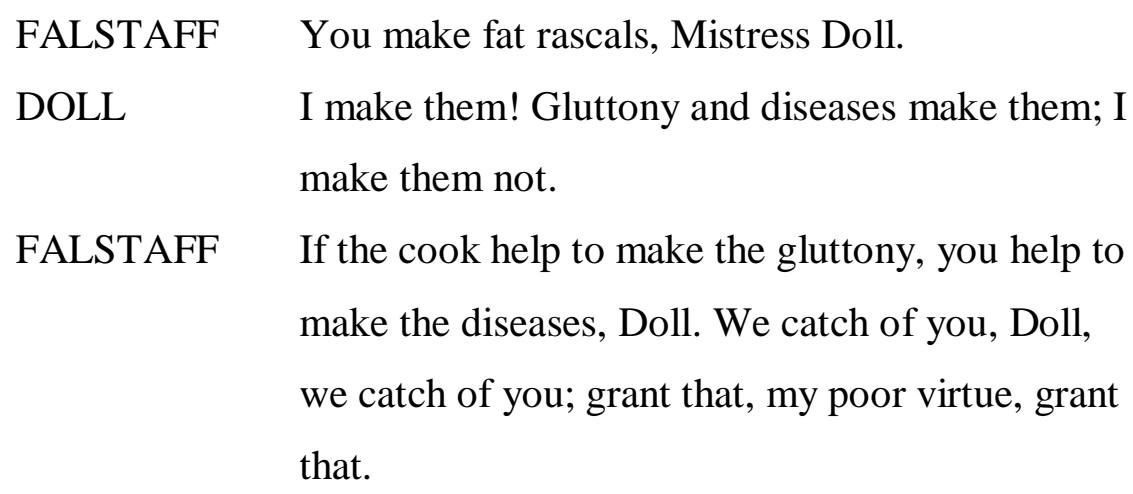

Doll is inclined to connect Falstaff's diseases to gluttony, but Falstaff disengages gluttony and disease to imply that Doll is spreading sexually transmitted diseases. The placement of Doll as the cook not the food in Falstaff's metaphor complicates the connection between disease and the consumer. Disease does not lie in the person of the prostitute, just as the cook does not directly cause gluttony; rather it is presented as a consequence of the immoral act itself. The presence of these diseases in Falstaff, then, attests to the immoral acts he has been party to, while his use of the plural serves to draw his diseases out to coat and corrupt the rest of society.

The gluttony, immorality, and disease, which are the cornerstones of Falstaff's role as Vice in 2 Henry $I V$, are further complicated by his concern for cash. In 1.2, links made between gout, pox, commodity, and wit provide as much comment on society as on Falstaff's character.

A pox of this gout! - or a gout of this pox! - for the one or the other plays the rogue with my great toe. 'Tis no matter if I do halt; I have the wars for my colour, and my pension shall seem the more reasonable. A good wit will make use of anything. I will turn diseases to commodity. 
The mention of commodity at the end of the speech firmly ties the concept of commerce to disease, while also suggesting that Falstaff intends to spread his illness about. Commodities, after all, must change hands to be of use. Though Falstaff is determined to make something of his diseases, the consumption of his purse remains a constant concern. Mistress Quickly, in 2.1, attempts to have Falstaff pay his debt to her, a debt intrinsically connected to the consumption of food and thus to his diseases. She declares, "He hath eaten me out of house and home. He hath put all my substance into that fat belly of his" (2 Henry IV 2.1.). Later, he does the same to Shallow, as he takes his money while eating his food and enjoying his hospitality. In 1 Henry $I V$, Falstaff is undoubtedly imperfect, but the audience is drawn to like him; the obvious bond of friendship and affection between Falstaff and the prince tempts us into viewing him as more a jolly scoundrel than outright immoral. In 2 Henry IV, however, Falstaff is being set up for the fall he is to take with Hal's rejection, and as such there is a concern with revealing him as morally bankrupt, whilst still allowing him to play the role of the fool. And so we come to a Falstaff who is quite literally bankrupt; his purse has consumption and "Borrowing only lingers and lingers it out, but the disease is incurable." (1.2.217-9).

Connections between gluttony and morality and gluttony and commodity serve to construct disease as a social issue. Eating and drinking were undeniably social events for the early modern audience, and so we find instances in Shakespeare where eating and drinking are made social issues in and of themselves. Falstaff's defence of sack is perhaps the most significant of these instances, worth quoting in extended form. Falstaff gives his account of the humoral adjustment sack causes as follows:

I would you had but the wit; "twere better than your dukedom.

Good faith, this same sober-blooded boy doth not love me, nor a man cannot make him laugh. But that's no marvel; he drinks no wine. There's never none of these demure boys come to any proof; for thin drink doth so overcool their blood, and making many fish meals, that they fall into a kind of male green-sickness; and then when they marry, they get wenches. They are generally fools and cowards - which some of us should be too, but for inflammation. A good sherry-sack hath a two-fold operation in it. It ascends me into the brain, dries me there all the foolish and dull and crudy vapours which environ it, makes it apprehensive, quick, forgetive, full of 
nimble, fiery, and delectable shapes, which, delivered o'er to the voice, the tongue, which is the birth, becomes excellent wit. The second property of your excellent sherry is the warming of the blood, which, before cold and settled, left the liver white and pale, which is the badge of pusillanimity and cowardice. But the sherry warms it, and makes it course from the inwards to the parts' extremes; it illuminateth the face, which, as a beacon, gives warning to all the rest of this little kingdom, man, to arm; and then the vital commoners and inland petty spirits muster me all to their captain, the heart; who, great and puffed up with his retinue, doth any deed of courage. And this valour comes of sherry. So that skill in the weapon is nothing without sack, for that sets it a-work; and learning a mere hoard of gold kept by a devil, till sack commences it and sets it in act and use. Hereof comes it that Prince Harry is valiant; for the cold blood he did naturally inherit of his father he hath, like lean, sterile, and bare land, manured, husbanded, and tilled, with excellent endeavour of drinking good, and good store of fertile sherry, that he is become very hot and valiant. If I had a thousand sons, the first human principle I would teach them should be to forswear thin potations, and to addict themselves to sack.

$(4.2 .78-111)$

The comedy of the piece is still quite apparent to us today even without a background in the humours. However, as Simpson argues, this section is not without firm roots in the popular medical literature of the time (42-3). In The Touchstone of Complexions we find the passage:

Now, there is nothinge more effectuall to make good \& perfecte digestion and to stirre up the Spirites, then sleepe, exercise, and wyne, so ye same be pure, good, and moderatelye used, as the other also must bee. For so doth it stirre up \& make syncere, lively and cleare Spirites, from whence proceedeth cheerefulnes, joy, quicknes and myrth of the minde. For the meates $\&$ nourishments (which by nature are laboured into humours) being eaten and washed downe wyth good and holsome wyne, have freer passage into all the parts 
of the body, and distribute theyr nourishment into them more effectually. There is nothing therefore that so much banisheth phansyes \& sorrow out of a mans minde [Note: Eccle. 31], as pleasaunt merye companye, and moderate use of wyne.

(Newton 5)

While Newton advises moderation, which is not mentioned in Falstaff's treatise (he encourages addiction), these passages show a marked similarity of logic. The similarity of these passages is not coincidence, but it equally should not be taken as causal. Hoeniger warns against attributing specific sources to Shakespeare's medical passages, due to the similarity between so many medical texts and the probability that much medical knowledge was common knowledge in the Renaissance due to scientific stagnation partially caused and certainly prolonged by the revival of classical texts $(32-33) .{ }^{19}$ Indeed, numerous other contemporary medical authors reproduce the same idea on wine. In Treatise of Melancholy Bright explains "Of all things of ordinarie use, the most speedy alteration is of wine: which in a moment repaireth our spirits, and reviveth us againe, being spent with heavinesse" (36). Not all medical authors present such positive descriptions of the effects of alcohol - William Bullien gives a much more critical description of the effect of wine, writing that "to be drunken with excesse it is a poison most venomous" (The Gouernment of Health 75). Ignoring contemporary warnings against excess and stressing the beneficial qualities of wine beyond the scope of most medical works, Falstaff is not producing his defence of sack from thin air or psudo-science, but he is adjusting existing medical arguments to suit his lifestyle. By sourcing much of Falstaff's argument from popular medical advice, Shakespeare creates a compelling image of wilful ignorance and social irresponsibility.

Shakespeare certainly uses Falstaff's physical diseases and moral flaws to mock both medical works which advocated wine as a remedy for humoral imbalance, and those who exploited the advice to justify their own gluttony. In considering Falstaff's speech on sack a skewed reflection of medical advice, the importance of moderation and excess must be considered. In Prince John, who drinks no wine, Falstaff presents a figure lacking, whose blood is "overcool" and who are prone to "green-sickness". ${ }^{20}$ He uses these references to

\footnotetext{
${ }^{19}$ In pages 115-6 Hoeniger notes the use of early modern medical ideas in Falstaff's passage on wine, and points to Bright as a possible source. Given that most dietaries contain similar passages, his earlier statement, to which I refer here, is more applicable in this instance.

${ }^{20}$ Green-sickness was a disease usually only attributed to women and serves here as a means to unman the prince Falstaff is alluding to, more than to suggest symptoms per se.
} 
disease to undermine and unman the prince who has scolded him (Fitzpatrick 28-29), and to create a negative image against which his argument will seem logical. The excess of this negative is especially evident when one considers the political implications of Falstaff's declaration that those like the prince will only have female children. Elizabeth I's father Henry VIII, desperate for a son, annulled his first marriage and cut the English church off from Rome (Elton 98-99). ${ }^{21}$ It is only at the end of his speech that Falstaff decouples the crown prince from this prediction saying "the cold blood he did naturally inherit of his father he hath, like lean, sterile, and bare land, manured, husbanded, and tilled, with excellent endeavour of drinking good store of fertile sherry" (4.2.) Falstaff seems quite ignorant of the logical failings of blaming Henry IV for a humoral balance likely to beget daughters; Hal has three brothers which does undermine Falstaff's judgement of his father. Against this illogically negative excess, Falstaff glorifies his excessive consumption using arguments associated with moderation. In describing in medical language the drying of the spirits and the warming of the blood, Falstaff pushes the benefits of wine into the excess. He attributes "excellent wit" and "valour" to sherry, and claims that skill and learning are useless without sack - shaping wine as a sort of cure-all for faults of character. In doing so he creates a sort of humorous juxtaposition between extremes of excess and deficiency. Any moderation in drinking is obscured by his labelling of his philosophy as "the first human principle" which requires an addiction to sack. The social disruption and poverty caused by alcoholism is utterly denied in Falstaff's description of excess, but it is obvious in his mannerisms and behaviour elsewhere. Here in his "defence of sack" the audience can see the failure of Falstaff's philosophies, and recognise the depths of his self-deception.

Ultimately, we laugh at Falstaff's failure to recognise his own failings. In defending his lifestyle, Falstaff further erodes audience sympathies as they are again confronted by his wilful obliviousness. His lengthy justification of sack would not be necessary if Falstaff drank in moderation, and yet if he were either moderate or truthful he would not be Falstaff. As with his curses against his gout or pox, he uses medical language to avoid his diseases rather than to cure them; continuing on as a disease of the state, even as the play progresses towards a cure.

As his loud advocacy of the benefits of wine suggests, Falstaff is shown to be rather fond of revels. The revels Falstaff advocates are wild, lewd, and riotous. They are also condemned by the authorities - to the extent that when Hal becomes an authority, he too

\footnotetext{
${ }^{21}$ See Elton "Chapter 4: Thomas Cromwell and the Break with Rome" for details about the initial separation of England from Rome.
} 
rejects them and Falstaff. Of course the appearance of both revels and censure in the plays is historically logical. The notable apprentice riots of 1592 and 1595 were loud, violent, and fuelled by alcohol (MacGregor 115). Much of Shakespeare's audience would have belonged to this demographic (MacGregor 110), while his more noble patrons and the censorship office needed to be presented with suitable authorities to counter the disorder of the revels. By positioning various diseased characters at the centre of the events, Shakespeare clearly connects the revels to infection, and sickness. This serves a twofold function: firstly the disorder of the revels may more easily be perceived as a disease of the body politic. Secondly Shakespeare is presenting a picture close to reality. Falstaff, for all his boasting, is one of the most 'real' characters in the play: his boasting is always undermined - often by himself - and he is clearly mortal. We may be saddened by his death in Henry $V$, but we are not surprised. While many critics have described him as 'larger than life', it would be more apt to call him 'large as life', for whether or not he is realistic, it is through his behaviour that we feel closest to the history with which we are presented. As when he uncovers the boasting of Shallow, he reveals the boast of history, and his diseases are an important aspect of the connection that Shakespeare is encouraging his audience to feel with the history he presents. Unlike in Henry $V$ we are not meant to take the events of the Henry $I V$ plays reverently, and with awe; rather, the audience is expected to laugh at the antics of an old beggar knight, who drinks with a prince. It is disease which takes this from a fairy tale situation into a sort of pseudo-realism to which Shakespeare's original audience could relate.

The role of revels as both a point of connection and a symbol of the sickness of the body politic is not exclusive to histories. In Twelfth Night we are introduced to Sir Toby Belch and Sir Andrew Aguecheek, whose very names refer to illness. In the microcosm of the household, as opposed to the macrocosm of the state, the presence of these two is alarmingly disruptive. Drawing on ideas of imbalance and diet, we have the exchange:

\footnotetext{
SIR TOBY Does not our lives consist of the four elements?

SIR ANDREW Faith, so they say, but I think it rather consists of eating and drinking.

SIR TOBY Thou'rt a scholar; let us therefore eat and drink.
}

Sir Toby introduces the idea of the humours to the conversation, to which Sir Andrew makes his witty response. The generation of humours is rooted in diet and Sir Andrew's response 
plays on this idea. That the audience is intended to interpret it as such is indicated by Sir Toby's proclamation that he is a scholar, both a mockery of his companion and an acknowledgement of the play on humoral theory. The further connection between vice and food is evidenced in the line "Dost thou think because thou art virtuous there shall be no more cakes and ale?" (2.3.103-4). Malvolio's virtue is not sufficient to override the vice of the revellers, and the steward's role as financial minister of the household is discounted. Sir Toby revels are an implied financial drain on the household: Malvolio longs to scold him because "you waste the treasure of your time with a foolish knight" (2.5.68-9 italics mine). However, there is none of the strong commercial focus found in 2 Henry IV and Troilus and Cressida in Twelfth Night; disease is instead all the more closely married to morality and status.

Issues of balance, health, status and morality are all turned into comedy in Twelfth Night. The poorly balanced nature of Sir Andrew's humours is consistently drawn on to construct jokes at his expense, and many of these jokes play on his social position as a knight. Sir Toby is often responsible for this mockery: "For Andrew, if he were opened and you find so much blood in his liver as will clog the foot of a flea, I'll eat the rest of th'anatomy." (3.3.52-4). Mocked as a natural fool and coward, Sir Andrew's moments of self-awareness are all the more poignant, and are certainly a part of what inclines some critics towards considering Twelfth Night a problem play rather than simply a romantic comedy (Bell 76).

The role food plays in establishing Sir Andrew's character is remarkable. When Sir Andrew earnestly pronounces, "Methinks sometimes I have no more wit than a Christian or an ordinary man has; but I am a great eater of beef, and I believe that does harm to my wit." (1.3.71-3), the confession that he eats a great deal of beef gives Shakespeare's audience a clue as to what sort of character Andrew is. Beef, especially dry beef, was believed to engender the cold humours (Bright 28). Knights were generally more associated with hot humours of choler and blood, as Falstaff describes in his defence of sack. The cold humours of phlegm and melancholy tended to be associated with cowardice, and phlegm with women and witlessness. With one off-hand confession about his beef-eating, Sir Andrew foreshadows all his cowardice and folly over the whole of the play, and provides the foundation for the 'duel' to comically parallel his and Viola's feminine natures.

Shakespeare's tendency to draw on common beliefs surrounding eating and drinking to provide audiences with markers for temperament, class, and disease did extend beyond the comic. Nowhere is this more striking than in the case of Poor Tom, the character constructed 
as a disguise by Edgar in King Lear. Edgar introduces himself disguised to his father by referring primarily to what his imagined character eats and drinks:

Poor Tom, that eats the swimming frog, the toad, the tadpole, the wall-newt and the water; that in the fury of his heart, when the foul fiend rages, eats cow-dung for sallets; swallows the old rat and the ditch dog; drinks the green mantle of the standing pool ...

(Lear 3.4.119-123)

Even today Poor Tom's diet is easily read as that of a madman. Though when he refers to eating frogs, toads, tadpoles, and wall-newts there is the suggestion that, with the inherent break signalled by the semi-colon, this is done when he is at his most lucid. So, while even for an early modern audience this passage would have been designed to shock, we should interpret at least some of these foodstuffs as being the result of desperation and indicative of social status. Indeed, Poor Tom consistently makes references to an imagined past as a wealthy individual, paralleling and foretelling Lear's social decline as well as his mental one. Poor Tom's disease leads to unusual eating habits, rather than eating habits engendering disease, reflecting the uncertainty of cause and effect which surrounded early modern beliefs of contagion and class.

\section{Exercise}

Cause and effect are further confused when one turns to Shakespeare's references to physical exertion and disease. Renaissance dietaries, intended as medical self-help books, tend to provide a wide range of activities which may be considered exercise. Newton lists exercises as:

As for Wrestling, Coytingo, Tennis, Bowlinge, Whorlehattinge, liftinge greate waightes, pitching the harre. Ryding, Running, Leapinge, shooting in Gunnes, swymming, tossing [the] Pyke, Tyltinge, Barryers and Tourney, are reckened amonge the exercises of strong men... 
There be other kinds of exercise not of so great travaile as these, and lesse troublesome: as to bee caryed in wagons, or to be rowed in Boates: sondrye sortes of frictions: walking eyther softly or apace, Singinge and Musicall melodie, chaunted eyther with liuely voyce, or played upon swete Instrumentes, to the eares \& mynde righte pleasaunt and delightfull, dryving awaye heauynes, and cheering and revyvnge the Spyrites, when they are damped wyth thoughtes, and carefull pensivenes. And if thereto be used a cleare and lowde reading of bigge tuned sounds by stoppes and certayne Pauses, as our Comicall felowes now do, that measure Rhetorick by theyr peeuish Rhythmes, it will bryng exceeding much good to the Breast and Muscles. ... I could heere repeate a great sort of other exercises moe, as Dyce, Tables \& Cardes, but because they bee the pastimes \& recreations of ydle persons \& to be done standing still or sittinge, and againe, be not in [this] nomber of commendable delights, \& laudable solaces, I have spared in this place to speake anye thing of them.

(The Touchstone of Complexions 53)

The violent and more riotous exercises Newton lists are, perhaps, the most significant manifestations of 'exercise' in these plays, and these in turn most strongly relate to disease within the body politic. Knights, who are associated with the exercises of strong men Newton lists, are generally responsible for social disease within these plays. The disturbing moral and physical illness referred to in 2 Henry IV or Troilus and Cressida cannot be used in the smaller social circles in Twelfth Night. It lacks the necessary war and political sphere. In Twelfth Night the knights, and their disruptive exercise, are limited to the subplot. Even within the subplot, the strenuous exercise of strong men is non-apparent. The sole 'battle' takes place between Voila and Andrew, and is a complete farce. It is the more disruptive exercise of revelry, not war, which leads to social disease. The violent potential of the knights does not have an outlet and, turned inwards to the micro state of the household, fuels the cruelty directed towards Malvolio.

Knights have been highly romanticised in more recent (Victorian) times; however, in Shakespeare's world they were still generally recognised as men of war. Though, that being said, even during Shakespeare's time this was beginning to change. The state had begun to 
sell knighthood to wealthy individuals in order to raise money. Sir Andrew was knighted "with unhatched rapier and on carpet consideration" (3.4.209-210) rather than on a battlefield, and his ineptitude in the 'duel' further emphasises the incongruity of his title. The increasing uncertainty regarding what it meant to be a knight allowed Shakespeare to depict the range of figures he does with the title of 'Sir', but almost invariably he uses these figures to point to moral disease within the state through their enjoyment of infectious revels and practical jokes.

The accusations thrown by Lear's daughters against his knights rely heavily upon the language of disease and contaigion. Goneril, with whom he first stays, draws on the miasma theory of contagion when she complains:

But other of your insolent retinue

Do hourly carp and quarrel, breaking forth

In rank and not-to-be-endured riots.

(Lear 1.4.176-8)

The rank nature of these riots leads to infection and disease within the court, as Goneril goes on to say:

Here do you keep a hundred knights and squires;

Men so disordered, so deboshed and bold,

That this our court, infected with their manners,

Shows like a riotous inn.

(Lear 1.4.216-219)

The description of these knights is in line with descriptions of Falstaff and Sir Toby, disordered, deboshed and bold, which may be taken to indicate a certain level of social concern surrounding the figures of knights. They are not described as handsome saviours, and if bold, it is a boldness fuelled by drink and leading to rioting. However, they are sheltered by the favour of those above them. While "[t]he shame itself doth speak / For instant remedy;" (Lear 1.4.221-2) Goneril does not have quite the necessary power to 'cure' the infection of her home. The knights are, after all, a military power which is able to destroy her if directly confronted. The knights' behaviour is condoned by Lear in this case and, so long as he retains the title of king, they may justify all. In a similar manner Malvolio is unable to expel Sir 
Toby and Sir Andrew from the household without the consent of Olivia, despite their riotous behaviour infecting the household (and it eventually 'infects' him). Falstaff likewise dreams of being a kept knight and his hopes lead him to race back to London on news of King Henry IV's death; however, Hal does not have a place for such sickness in his state and Falstaff dies of his own 'little kingdom's' infections.

\section{Miasma}

While many references to eating, drinking, and physical exertion can manufacture uncertainty as to whether the disease is caused by the activity, to be cured by the activity, or if the activity is a symptom of the disease, use of miasma theory invariably indicates the cause of the disease. Early modern miasma theory speculated that the state of the air in an area could dramatically affect an individual's health. Without modern scientific techniques or technology, the quality of the air was largely judged according to how good or bad it smelled. Belief that bad smell could cause harm was rooted in long tradition and some basic logic even today the smell of mould alone is enough to keep a house unsold. Sweet smelling herbs were brought into houses and were believed to be as effective as flea-bane at keeping diseases at bay. Foul smells on the other hand were to be avoided when possible; the Roman architect Vitruvius theorised that the smelly mists of swamps, such as those in Rome, were extremely unhealthy and cities should not be established near them (1.4.1). ${ }^{22}$ Early modern physicians tended to come to similar conclusions regarding the smell of the Thames and the source of the plague. In literature the idea of positive and negative scents add immensely to sensory descriptions of characters, not only encouraging descriptions of scents, but also adding meaning to them.

The link between disease and bad smells is integral to characterisation and the development of the theme of corruption in Troilus and Cressida. Unsavoury aromas are used to isolate Theristes from the other characters and label him as a disease of the state. The highly pessimistic critic of the play world is described as "rank" (1.3.72) before he even appears onstage. From the outset, then, the audience is to identify Thersites as a source of disease. And when he does appear, it is as a contagion. 2.1 opens with him being immediately identified by name in line one, and he begins to compare Agamemnon to a boil in 2.1.2-9.

\footnotetext{
${ }^{22}$ In Rome the malarial mosquitoes rarely frequented higher altitudes, where coincidentally air was fresher. This seemingly confirmed the theory. The hilltops in Rome were, incidentally, prime real-estate and owned only by the wealthiest families.
} 
His first act of the play is to infect the metaphor of the body politic, and the audience's opinion of Agamemnon. Indeed, Thersites consistently throughout the play depicts other characters as diseased in his vicious railing. It is unlikely that we are intended to take Thersites' condemnations at face value, but they do serve to set the tone of the play whether or not we choose to believe them. E. A. M. Colman calls Thersites "more a byproduct of the long war than a force in it" (120), and it is true he does not impact the action of the play, but I would go so far as to call him a physical representation of the war's diseases; a symptom of the state's decay as much as a commentator on it.

Shakespeare does not simply produce a rank environment to continue the idea that the enterprise is sick; he also employs the idea of miasma in a social context. This is especially relevant to the characterisations of Pandarus and Helen. Shortly before Pandarus' exit in 1.1, Troilus uses the term 'sweet' in "Sweet Pandarus" (1.1.82), imploring Pandarus to continue his support of the Trojan enterprise, the wooing of Cressida. Later in 3.1, when Pandarus meets with Helen and Paris, the word sweet is used twenty times. Helen herself, in the same scene is referred to as 'sweet' at least 15 times. Sweet is obviously a positive word in general; in terms of early modern disease it indicated health. However, overuse of the term changes the beneficial connotations and places them under suspicion. In Troilus and Cressida this is certainly the case, as Thersites objects to this deceptive use of the word 'sweet' in an aside: "Sweet draught! 'Sweet', quoth a? Sweet sink, sweet sewer."(5.1.67-8). This comes in act 5, and aligns with established concerns about the word 'sweet', confirming the negative intent of the word. While we may be suspicious of 'sweet', it is important to realise the roots of the use reside in miasma theory. It is not sweetness of taste which is relevant here but of smell, and when things rot they give off a sweet smell. In Much Ado About Nothing the pivotal line, "Give not this rotten orange to your friend" is playing off the same idea: sweet smell is revealed as rot, and symbolises disease.

In Much Ado About Nothing the threat of disease, the rot, is founded on Hero's purported lascivious behaviour. In Troilus and Cressida the term is heavily used around Helen, who has already been established as whorish before 3.1, and Pandarus, whose name is a dead giveaway. ${ }^{23}$ By connecting 'sweet' to the characters whose moral corruption is most obvious, the word gains currency within the play as a metaphor of moral infirmity. From this point of infection in 3.1 usage of the term spreads, with most characters called 'sweet' at one point or another. For instance, during the infamous 'kissing scene', both Agamemnon and

\footnotetext{
${ }^{23} 3.1$ also ends with Helen being sent to 'unarm Hector'; a panderer is a pimp.
} 
Ulysses call Cressida 'sweet'. In Agamemnon's line the use may be innocent, but when Ulysses asks "May I, sweet lady, beg a kiss of you?" (4.6.48) the repetition may be viewed as suspect (especially given the speaker). Ulysses' denounces her to Nestor as a whore in lines 55-64, confirming the suspect use of the word 'sweet'. By concealing contamination in this manner, Shakespeare encourages his audience to view the characters, their motives, and the action of the play with suspicion. In suspecting all is not well, the audience is prompted to think and consider the implications of a flawed heroic.

\section{Sleep}

As a cure for mental worries sleep has long been advocated. Early modern physicians understood the importance of sleep to health, especially mental health. The obvious impact of poor sleep on mood could easily be explained through the humoral system; it was regarded as a behaviour which affected the body's ability to digest food and manufacture humours. However, sleep also had spiritual or mystical implications, with dreams possessing a strong cultural currency for playwrights. In A Midsummer Night's Dream, sleep and dreams play an important role in the plot, with characters becoming vulnerable to fairy magic when asleep. The play concludes with Robin Goodfellow telling the audience:

If we shadows have offended,

Think but this and all is mended:

That you have but slumbered here,

While these visions did appear;

And this weak and idle theme,

No more yielding but a dream,

Gentles, do not reprehend.

If you pardon, we will mend.

(Epilogue 1-6)

The 'visions', 'dreams', and 'shadows' of the Epilogue are all evocative of the magic upon which the plot has hinged. And yet, even the magical slumbers of A Midsummer Night's Dream correspond with humoral theory and suggest contagion. The juice of the love-inidleness Oberon sends Robin to find "[w]ill make man or woman madly dote" (2.1.171 italics 
added), and love itself is a sickness in the play. Demetrius hates Helena's love and says to her, "Tempt not too much the hatred of my spirit; / For I am sick when I do look on thee", to which she responds, "And I am sick when I look not on you." (2.1.211-213). Movement of the spirits and perturbation of the humours caused by love were believed to lead to sickness for centuries before Shakespeare. His use of sleep to divide the mood-changes which define the play draws, in part, on the similar perturbation sleep and sleeplessness were believed to cause.

Reference to sleeplessness is used in both 2 Henry IV and King Lear to emphasise the exacerbation of the disease and isolation suffered by the kings. Insomnia in 2 Henry IV draws the experience of both kingship and disease away from concerns of the body politic, making it a very private matter. King Henry laments his sleeplessness:

How many thousand of my poorest subjects

Are at this hour asleep? O sleep, O gentle sleep,

Nature's soft nurse, how have I frighted thee,

That thou no more wilt weigh my eyelids down

And steep my senses in forgetfulness?

Why rather, sleep, liest thou in smoky cribs,

Upon uneasy pallets stretching thee,

And hushed with buzzing night-flies to thy slumber,

Than in the perfumed chambers of the great,

Under the canopies of costly state,

And lulled with sound of sweetest melody?

O thou dull god, why liest thou with the vile

In loathsome beds, and leavest the kingly couch

A watch-case or a common 'larum-bell?

Wilt thou upon the high and giddy mast

Seal up the ship-boy's eyes, and rock his brains

In cradle of the rude imperious surge

And in the visitation of the winds,

Who take the ruffian billows by the top,

Curling their monstrous heads and hanging them

With deafening clamour in the slippery clouds,

That, with the hurly, death itself awakes? 
Canst thou, O partial sleep, give thy repose

To the wet sea-boy in an hour so rude,

And in the calmest and most stillest night,

With all appliances and means to boot,

Deny it to a king? Then happy low, lie down!

Uneasy lies the head that wears a crown.

Alone onstage, Henry is presented as isolated physically by his disease and personally by his status. The audience is allowed to glimpse a very human character, whose experience contrasts sharply with that of Hal as prince. Henry distances himself from his subjects by emphasising the divide between their basic experience of sleep and his lack of the same. Up to this point Hal, on the other hand, has always been presented alongside a representative of the common man. The significance of this contrast becomes evident in the final line, "Uneasy lies the head that wears a crown" (3.1.31). Henry pulls back from personal experience enough to generalise in this last line. It is not his experience of kingship, but every experience of kingship that may be characterised by uneasy sleep. Indeed, in Henry $V$, having ascended the throne Hal spends a sleepless night wandering before the battle of Agincourt. However, Hal in his sleeplessness does not divide himself from his subjects; rather he seeks to renew the common bond he fostered in 1 Henry IV and 2 Henry IV.

While Henry's soliloquy pulls away from concerns of the body politic and into individual musing, the insomnia is still shaped as an interpersonal concern. The "many thousand", the "vile", and the "ship-boy" with whom the speech engages are used to create an almost antagonistic division of the king from his subjects. And yet, by using these figures as a frame of reference, for comparative effect, sleeplessness becomes an undeniably interpersonal concern. It is the interpersonal nature of Henry's lament which makes sleeplessness a significant disease in of itself as much as a symptom of disease. In being able to compare his experience with others, Henry is shown as becoming more and more distressed by his own circumstances. He moves from soft phrases like "gentle sleep" and "nature's soft nurse" to harsh ones such as "the rude imperious surge". The juxtaposition of 'harsh' and 'gentle' encourages an interpretation of Henry as mentally disturbed - a disease rooted in the insomnia. Warwick, blurring the lines between advisor and physician, tells King Henry: 
Please it your grace

To go to bed. Upon my soul, my lord,

The powers that you already have sent forth

Shall bring this prize in very easily.

To comfort you the more, I have received

A certain instance that Glyndŵr is dead.

Your majesty hath been this fortnight ill,

And these unseason'd hours perforce must add

Unto your sickness.

(2 Henry IV 3.1.93-101)

Where elsewhere advisors play physician to the state, Warwick here is providing medical advice to the king on a more individual level. The comfort of Warwick's good news and the return of the state to good political health is insufficient to miraculously cure the king. The metaphoric nature of the body politic is never more felt than here with the decline of Henry IV. Warwick, taking on the role of a medical physician, stresses the importance of both a calm mind and sleep to health, and yet when he does, the health of the king is shown to be becoming divorced from the political health of the kingdom. Warwick's advice allows the declining health of the king to be established as a more personal issue, one which the health of the body politic and the state's diseases stretch beyond.

Sleep appears as a potential cure for a troubled mind in King Lear, where it also serves to emphasise the movement from the position of king to that of an invalid. While it is especially evident in the case of Lear that the primary cause of his madness is perturbation of the mind, sleep and rest are stressed by Kent as necessary for the King's recovery. When Lear is finally coaxed in from the storm and put to bed, news comes that the party must leave at once. Kent laments at this news, saying:

Oppressèd nature sleeps:

This rest might yet have balmed thy broken sinews,

Which, if convenience will not allow,

Stand in hard cure.

(King Lear 3.6.90-3) 
As with Warwick's advice to King Henry, Kent's lament serves to illustrate the severity of Lear's illness. His disease, which the audience has witnessed progressing at an alarming rate, will now "[s]tand in hard cure", and the decay in Lear's mind comes to be reflected in the decay of order elsewhere in the play. Lear's madness does not come with a divorce from the metaphoric body of the state; indeed Lear's kingship is stressed alongside his abandonment. Sleep is here as much seen as a means of returning Lear to the state of a king as to a state of health. But, by the end of the play, it is quite evident that Lear is in no condition to rule his kingdom.

In both King Lear and 2 Henry IV sleep plays an important dramatic role in the final stage of the kings' illness. For Lear it allows him pathetic clarity, and a dramatic reconciliation with Cordelia to mirror his rejection of her in the first act. When Cordelia seeks to have Lear take up his sovereignty, calling him "royal lord" and "majesty" (4.7.44), Lear calls himself "a very foolish fond old man" (4.7.61). In the end Lear mirrors his first act of the play, removing from himself the power and responsibilities of state, only now recognising them to be one and the same. We find the reunion of Hal and King Henry is also preceded by both sleep and music, in both cases sleep is able to revive the kings back to health for a time, but their health does not last beyond the necessary reunion of father and child. Through the death of the old and diseased, the state is returned to moral health, order, and heroism.

\section{Perturbation of the Mind}

Sleeplessness in these plays appears as a symptom and secondary contributing factor to the diseases of the kings. Worry and stress - perturbation of the mind - are presented as the primary causes of Henry IV's and Lear's illness. Medical science today draws links between stress and disease so the cause of the main characters' descent into madness is plausible with or without an understanding of early modern medicine. However, to an early modern audience the effects of a perturbed mind could be physical and deadly. King Henry IV suffers from a physical disease which is consistently connected to a perturbed mind, and the worries of kingship. Even after he hears good news his health fails, and Clarence explains:

he cannot long hold out these pangs.

Th'incessant care and labour of his mind 
Hath wrought the mure that should confine it in

So thin that life looks through and will break out.

There is the sense that the damage has already been done by the worries of the state, and removing them can no longer help. Hal later says to the crown "The care on thee depending / Hath fed upon the body of my father" (4.3.286-7). The phrasing of these lines plays on the relationship between eating and disease. As I have previously discussed, eating was strongly connected to disease, but here we have a different form of contagion eating away the person through disease. The cares of kingship are presented as having a very physical effect on the king, here eating away his body more than his mind.

In King Lear we are continually reminded of the cause of Lear's deteriorating mental state by Lear himself. Appalled by his daughters' treatment of his own stately majesty, he begins obsessing about their relationship to him and their perceived betrayal, saying,

But yet thou art my flesh, my blood, my daughter;

Or rather a disease that's in my flesh,

Which I must needs call mine. Thou art a boil,

A plague-sore, an embossed carbuncle,

In my corrupted blood.

(King Lear 2.4.216-220)

The metaphorical construction of Goneril as a disease of the flesh is so effective because it draws heavily on Lear's state of mind. Angered and troubled by her assertiveness, Lear does not simply argue that she will cause him to become diseased, but that she is a disease. This link between daughters and disease persists for some time. Later, when he meets Edgar, he speculates that only a man's own daughters could drive him so into madness. The mental distress caused by the betrayal of a loved may be universally relatable, but should not be universally applied. Lear's daughters become both the cause of his mental illness and, in references, a continued symptom of his disease.

Lear's distress is based not on state matters, but rather on familial matters: his daughters' rejection of him. But, because he is a king, Lear cannot confine his sense of betrayal within regular bounds. As his mental stress worsens his disease, he draws increasing connections between his own circumstances, justice, and the laws of the state as a whole. 
Lear's obsession leads to the pitiful trial scene in 3.6, in which he attempts to achieve an imaginary victory over his daughters. This culminates in Lear saying,

Then let them anatomize Regan; see what breeds about her heart. Is there any cause in nature that makes these hard hearts?

(King Lear 3.6.70-3)

In ending his mock trial on a question, Lear may seem unresolved. His decree to anatomize his daughter is not a question, however, though it is related to it. During the early modern period the Royal College of Physicians was granted the cadavers of recently executed criminals by the monarch in order to study anatomy (Clark 122). To anatomize is to dissect, and for Lear to give his daughter over for dissection is extreme enough, but Lear makes no mention of execution, which suggests vivisection. The punishment for common traitors was to be hanged, drawn, and quartered, which involved a sort of vivisection as the organs were methodically removed whilst the subject was still alive. To even suggest prescribing a punishment like this to a princess is transgressive. In announcing a desire to anatomise Regan, Lear's hatred and stress is shown to have infected his sense of social order and justice.

Even in the worst of his madness, Lear is unable to escape his own anger at his daughters. This perturbation of his mind has him transgress even the laws of God. In his ranting he acquits adulterers, saying "Let copulation thrive; for Gloucester's bastard son / Was kinder to his father than my daughters" (King Lear 4.6.112-3). The Ten Commandments forbid adultery, and divine law was held to be one of the checks of a king's power. Jean Bodin, defining sovereign power, writes,

But as for the lawes of God and nature, all princes and people of the world are unto them subject: neither is it in their power to impugne them, if will not be guiltie of high treason to the divine majestie, making warre against God;

(The six bookes of a common-weale 92).

The sinful disorder Lear advocates is, thankfully, curtailed by his powerlessness. That his reaction to being wronged is to allow lesser wrongs complicates how we must view Lear's madness and his right to rule. Even when he cries out against injustice in the state as a whole there are issues with the conclusions he draws: 
Thou rascal beadle, hold thy bloody hand!

Why dost thou lash that whore? Strip thine own back;

Thou hotly lusts to use her in that kind

For which thou whipp'st her. The usurer hangs the cozener.

Through tattered clothes small vices do appear;

Robes and furred gowns hide all. Plate sin with gold,

And the strong lance of justice hurtless breaks:

Arm it in rags, a pigmy's straw does pierce it.

None does offend, none, I say, none; I'll able 'em:

Take that of me, my friend, who have the power

To seal the accuser's lips. Get thee glass eyes;

And like a scurvy politician, seem

To see the things thou dost not.

(4.6.154-166)

The only remedy to injustice his broken mind can conceive of is silencing the accusers, which does nothing to prevent the vices which decay his state and power. His decree that, "none does offend, none, I say, none" (162) harks back to Cordelia's "Nothing" in Act 1. There Lear bound himself by his own decree, despite his sovereign power. Bodin stresses that sovereign power cannot limit itself by its own laws, only those of God or nature have power over him (91-2). It seems that here, in his madness, Lear is haunted by his deliberate and unnecessary injustice towards Cordelia and, perturbed, his ranting on the injustice in his state loses its focus, and he must admit that he is "cut to the brains" (4.6.187).

Social perceptions of disease, which linked it to immoral behaviour and excess, meant Shakespeare was able to use disease to highlight interpersonal concerns within his plays. Falstaff's excess becomes representative of society's disease and moral corruption at once. The religious connotations of infection obviously have influenced the reception of these diseased behaviours, and while I have not explicitly discussed them, they are obviously functioning in the moral condemnation of the riotous characters. The relationship between social disorder, disease, and status which can be seen in Shakespeare's use of the "nonnaturals" adds to his use of the body politic analogy. States are both politically and socially diseased, and the manner in which disease functions in the relationships between characters and between characters and the state creates an atmosphere of tension. It is the 
personal suffering of disease, however, which connects the tension within the play world to the audience, and the depiction of suffering which has helped keep disease functioning within these plays across the centuries. 


\section{Chapter Three: Suffering - Mental Disturbance and Social Disorder}

It is obvious throughout his works that Shakespeare had a firm grasp of the narrative potential of madness. In the previous chapter I investigated many of what were believed to be the causes of ill health, including mental decay, and in doing so it became evident that Shakespeare emphasises perturbation of the mind in his descriptions of madness above all the other potential disruptors of the humours as it allows him to draw the audience's attention to the main issues of the play. Mental illness is the most tangible form of disease in the text of Shakespeare's plays and in both King Lear and Twelfth Night madness takes centre stage. ${ }^{24}$. While disease functions as a metaphor for disorder in the body politic, as shown above, it is also suffered on an individual basis. The depiction of suffering is focused on the individual characters, and the characters are always placed into a social order meaning madness is often used to problematize order and emphasise class divides. The madness we see in Shakespeare's plays is a literary construction of madness, one in which the symptoms and the behaviour of the diseased have thematic significance, and so the suffering of the characters must be interpreted in a literary more than a medical manner. Madness, then, is used to deliberately highlight political and social issues, and to evoke an emotional response from the audience about said issues.

Thus far I have discussed disease within the state and the social and moral issues interwoven with the acquisition of disease. Now, in turning my focus to the suffering of mental illness, I use this chapter to discuss not only the social disruption caused by disease, but also the role disease plays in reinforcing class boundaries and roles. In King Lear Shakespeare brings to the fore the debilitation caused by mental illness, as madness is used to bring Lear down to the status of his lowest subjects, the disenfranchised and insane, even as he simultaneously inhabits the role of king. In turn, this allows Shakespeare room to comment on the fallibility of kings, issues of state and rule, and bias in law. Twelfth Night stresses the antic behaviour that the title suggests by its reference to the night of misrule. From the lovesickness which permeates the main plot to the tormenting of Malvolio, madness emphasises class divides, and vulnerability, and raises questions surrounding the treatment of madness in society.

\footnotetext{
${ }^{24}$ It is, perhaps, paradoxical that the least visible form of disease - mental illness - has left behind the most compelling evidence in the text of the plays. For the most part, we can only speculate as to how actors may have applied make-up or acted in order to represent physical maladies, but the words which provided the foundation for the madness of these characters remain.
} 


\section{Madness in King Lear}

It is perhaps testament to Shakespeare's genius that there has been such a debate over whether or not to read Lear as mad from the beginning of the play. The verisimilitude is such that numerous medical doctors and critics have attempted to diagnose and discuss in medical terms the madness of this fictional character. ${ }^{25}$ Within these discussions there is a widespread concern about how mentally disturbed a person must be to be considered 'mad'. Given the integral nature of mental disease to the repentance of Lear and his movement towards a sort of redemption, it is tempting to believe that Lear begins the play in good mental health. Arguments for Lear's health at the beginning of the play choose to read Lear as rash but capable of reason, and argue that insanity requires the absolute loss of recognisable logic. However, arguments for Lear's ill health from the opening of the play are persuasive. Anthony Ellis is especially notable here for the firm basis of his argument in early modern medical belief concerning the humours. He draws attention to the shaping of old age in conjunction with humoral change, connecting old age to infirmity of both body and mind; the infirmity of Lear's age exists from the beginning of the play and its early modern implications should not be ignored (19-20). King Lear, then, is less a play about losing sanity, and more one about mental decay. Lear's disinheritance of Cordelia and banishment of Kent are unreasonable acts which clearly display his excess of choler at the opening of the play, and the perturbation of the mind caused by Regan and Goneril merely exacerbates his condition, it does not cause it.

Madness and kingship are intertwined in the person of Lear, and the impact his madness has upon the body politic is clear. Aware of his infirmity, to an extent, Lear divides his kingdom but attempts to retain the respect of his subjects even as he gives away the responsibilities. Lear "is not alone a mad man but a mad king" (Bucknill 171) in the play, but the giving away of his power is, in itself, an act of madness, which then leads to his social fall (Munson 18). The principles of the body politic play a part in how we must understand the play. In dividing his kingdom, Lear introduces a potentially deadly disease to the body

\footnotetext{
${ }^{25}$ Particularly notable amongst these medically focused critics are John Bucknill, H. Somerville and R. R. Simpson. Hoeniger gives an overview of medical criticism of Lear from 307 to 312, then goes on to demonstrate the importance of early modern medical concepts to the depiction of Lear's madness. Also of note is Rebecca Munson's "'The Marks of Sovereignty": The Division of the Kingdom and the Division of the Mind in King Lear" provides an excellent overview of the political issues of Lear's madness.
} 
politic, imposing his disease forcibly onto the state. To a Renaissance audience the division of the kingdom would certainly be regarded as an unreasonable and highly illogical act given the close relationship between the king and the state (Rose 47). In matters of state, however, there could be no argument of the incapability of the king to rule. Ernst H. Kantorowicz, in his book The King's Two Bodies, quotes a case from 1562 concerning the actions of the late Edward VI, wherein the lawyers concluded:

no Act which the King does as King, shall be defeated by his Nonage. For the King has in him two Bodies, vis., a Body natural, and a Body politic. His Body natural (if it be considered in itself) is a Body mortal, subject to all the Infirmities that come by Nature or Accident, to the Imbecility of Infancy or old Age, and to the like Defects that happen to the natural Bodies of other People. But his Body politic is a Body that cannot be seen or handled, consisting of Policy and Government, and constituted for the Direction of the People, and the Management of the public weal, and this Body is utterly void of Infancy and old Age, and other natural Defects and Imbecilities, which the Body natural is subject to, and for this Cause, what the King does in his Body politic, cannot be invalidated or frustrated by any Disability in his natural Body.

(Edmund Plowden Commentaries or Reports 212a

Quoted in Kantorowicz 7)

The distress of Kent seems to stem from such legal boundaries as these. Cordelia has no recourse to the law, despite her father's infirmity, nor can Lear regain the power he has given away. He grants to Cornwall and Albany "[t]he sway, revenue, execution of the rest" (1.1.137) and retains only the name and prerogatives of a king. Having used his power to give away his power, Lear is no longer possessed of the two bodies of a king; he has beheaded the state and no longer has the power to do as Kent begs and reverse his doom (1.1.149). Lear's selfish intent "[t]o shake all cares and business from our age" (1.1.37) focuses upon his natural body, and, put into practice, all but destroys his political body.

Lear's near complete destruction of his own political power cannot be viewed as anything other than mad when the early modern context of the play is taken into account 
(Munson 26). The political ramifications of the act are wondered at by Gloucester when he enters in 1.2:

Kent banished thus? and France in choler parted?

And the king gone tonight? subscribed his power?

Confirmed to exhibition? All this done

Upon the gad?

In piling up the questions in this passage, the audience is invited to share in Gloucester's incredulity at the turn of Lear from all powerful king to an "exhibition" from one scene to another. Here, of course, Gloucester means that Lear retains only a show of power, but one cannot help but recall Maria's intent to make "a common recreation" (2.3.121) of Malvolio in Twelfth Night. There is something fundamentally showy about madness in these plays. King Lear unwittingly makes an exhibition of himself, and his ignorance concerning the ramifications of his actions only leads to a continuing theatricality in his behaviour as he falls further into madness.

The appearance of the Fool after Lear has given up his political power marks the beginning of Lear's descent towards becoming a common recreation. The Fool's role is to provide Lear with recreation, but when he appears in 1.4 he launches directly into a chastisement of the powerless king. His jibe that the king is out of favour in 1.4.85 highlights the issue that makes Lear's position impossible. ${ }^{26}$ The king is the one meant to bestow favour, being the highest power in the kingdom, but Lear has given away that position, even though he retains the title and delusions. The Fool, of course, tells him he is a fool: "All thy other titles thou hast given away; that thou wast born with" (1.4.130-1). While the Fool is more suggesting a level of witlessness, Lear has nothing left but the theatricality of a fool or madman. When Goneril censures Lear for the revels of his followers, he asks quite dramatically “Are you our daughter?" (1.4.93), then when she asks him to have some decorum (1.4.194-8) he replies:

Doth any here know me? This is not Lear.

\footnotetext{
${ }^{26}$ The Fool offers Kent his coxcomb, insisting he must take it "for taking one's part that's out of favour", thereby implying that Kent is a fool. He then goes on in subsequent lines imply that Lear is a fool for giving away all his "living" (1.4.87-93) using the same coxcomb image.
} 
Doth Lear walk thus? speak thus? Where are his eyes?

Either his notion weakens, his descernings

Are lethargied - Ha! Waking? 'Tis not so.

Who is it that can tell me who I am?

(1.4.201-205)

As a King, with his political body intact, Lear would have stood above censure or reproach such as Goneril heaps on him. Without all the pomp of power, Lear's questions are cheap theatre, discounted by Goneril as one of his "new pranks" (1.4.213). Confronted with his selfimposed insignificance Lear flies into a rage, but, tellingly, falls into the rhetoric of curses the language of the disenfranchised, and the only means by which they can gain retribution in Shakespeare's plays.

Disenfranchisement is one of the great concerns of King Lear, and the spectacle of Lear and Edgar's relationship emphasises the destitute fate of many early modern mad people. In contrast with Twelfth Night, where Malvolio successfully rejects the madness with which he is threatened, in King Lear characters fail and fall into raving madness and poverty simultaneously. As the playwright constructs Lear's madness, he also creates a character who creates a mad character himself. Edgar decides that the best way to avoid capture and death at the hand of his own father is to create the persona of 'poor Tom' the madman. His construction of this character is significant and is thus quoted at length:

\section{Whiles I may 'scape,}

I will preserve myself; and am bethought

To take the basest and most poorest shape

That ever penury, in contempt of man,

Brought near to beast. My face I'll grime with filth,

Blanket my loins, elf all my hair in knots,

And with presented nakedness out-face

The winds and persecutions of the sky.

The country gives me proof and precedent

Of Bedlam beggars, who, with roaring voices,

Strike in their numbed and mortified bare arms

Pins, wooden pricks, nails, sprigs of rosemary;

And with this horrible object, from low farms, 
Poor pelting villages, sheep-cotes, and mills,

Sometime with lunatic bans, sometime with prayers,

Enforce their charity. Poor Turleygod! Poor Tom!

That's something yet! Edgar I nothing am.

(King Lear 2.3.5-21)

The mad people Edgar bases his character on are not figures elevated by suffering. The madness he describes is uncomfortable for both the sufferer, who is subject to the persecutions of the sky and themselves, and the people, whose charity is enforced by the sight of these figures. Edgar bases his character on a wholly unliterary example of madness; however, in consciously mimicking madness, he recreates it as a spectacle. When Lear in turn mimics Edgar's mimicry, madness is turned into drama.

The perceived degradation of humanity in madmen is not so much introduced as emphasised in Edgar's description of the insane wanderers. Shakespeare's madmen are based on contemporary popular treatment of such figures. With the dissolution of the monasteries in the time of King Henry VIII, rural England lost much of its medical support for both physical and mental ailments (Fabricius 74). While in London Bedlam remained open, there were precious few other hospitals for the insane and families were relied on to take care of ill relatives. The "Induction" to The Taming of the Shrew presents an example of a lord cared for by his household as Sly is fooled into believing he is a lord who has been mad. Sly is told, "Look how thy servants do attend on thee, / Each in his office, ready at thy beck." (Taming of the Shrew Induction 2.31-2). In Twelfth Night Sebastian wonders if Olivia is mad, but then concludes:

\section{Yet if 'twere so}

She could not sway her house, command her followers,

Take and give back affairs and their dispatch

With such a smooth, discreet, and stable bearing

As I perceive she does.

In both these instances it is presumed that the mad person will remain a part of the household and well cared for; though they may not remain directly in charge of their estates, they are cared for by them. The examples of madness found in Lear do not fit with this concept of 
care; rather, we see in Lear's plight the common Renaissance image of the wandering madman (Gilman 22). Edgar is disenfranchised by his half-brother Edmund, and at no fault of his own he is forced to take on the guise of a madman. His character 'poor Tom', on the other hand, is presented as having been a lover of wine, women, and gambling (3.4.84-5). If we can take Falstaff's financial circumstances as an example, the lifestyle Edgar describes had distinct links to poverty. In turn, this serves as an explanation for his lack of any care; only wealthy madmen could expect to be looked after.

Lear, of course, has enforced his own wandering. In raging at his daughters he merely gives them an excuse to abandon his care. It must be remembered that it was Lear's decision to leave his daughters and go out into the storm. While his daughters are certainly not free of blame, Lear is persistently the cause of his own undoing. Indeed, at this point it may be argued that Regan and Goneril are no longer his daughters, given that he has disowned them, though this would only stand unchallenged had Lear's political body been any more than tatters at this point. Devoid of wealth or family, Lear is both destitute and insane; circumstances which lead the fallen king to wander the countryside with Poor Tom.

Lear and Edgar are clearly placed into parallel situations: both are cast out from their homes, and both are presented as mad. And yet there are a number of important distinctions between the two. The 'show' of madness given by Edgar is clearly different from the visual spectacle of Lear's true insanity. Edgar's 'poor Tom' character is largely nonsensical in his speeches and his madness does not progress in any way. Lear, on meeting Edgar, tells him:

Why, thou wert better in thy grave than to answer with thy uncovered body in this extremity of the skies. Is man no more than this? Consider him well. Thou owest the worm no silk, the beast no hide, the sheep no wool, that cat no perfume. Ha! Here's three on's are sophisticated! Thou art the thing itself; unaccommodated man is no more but such a poor, bare, forked animal as thou art.

By the time they part, Edgar is out of inspiration for poor Tom's nonsense, saying "Poor Tom, thy horn is dry" (3.6.69). Lear on the other hand has completely forgotten who poor Tom is, and is losing his grip on reality. He addresses Edgar, saying, "You, sir, I entertain for one of my hundred; I do not like the fashion of your garments. You will say they are Persian; 
but let them be changed" (3.6.72-4). Edgar's manufactured madness can only extend so far. While it is extreme, it cannot develop as Lear's natural insanity does.

For all Edgar may shed his clothes and talk gibberish, he remains sane and noble, while Lear declines socially and mentally as truly as possible given the divine nature of kings. Indeed, to emphasise the difference between feigned and 'real' madness, Edgar remains onstage to soliloquise at the end of 3.6 and, in musing on Lear's decline, breaks from the character of poor Tom:

When we our betters see bearing our woes,

We scarcely think our miseries our foes.

Who alone suffers suffers most i'the mind,

Leaving free things and happy shows behind:

But then the mind much sufferance doth o'erskip

When grief hath mates, and bearing fellowship.

How light and portable my pain seems now,

When that which makes me bend makes the king bow;

He childed as I fathered! Tom, away!

(King Lear 3.6.95-103)

The sight of Lear, it seems, is sufficient to help prevent Edgar falling into despair. His remark that "Who alone suffers suffers most i'the mind" foreshadows a further decline in Lear, even while it restores our faith in Edgar's sanity. Edgar's observation that "that which makes me bend makes the king bow; / He childed as I fathered" seeks to equate his own experiences with Lear's. The equation, when observing the plot as a whole, is flawed. Cordelia and Edgar have more in common, being true to fathers who reject them, than Edgar and Lear whose betrayals are not consistently analogous. Indeed, Lear is, at least in part, responsible for his own condition, cast out by his own infirmity, while Edgar has been duped and betrayed by his brother Edmund and cast out by his father.

In later Acts, Gloucester proves a better companion and parallel to Lear's madness. Though physically debilitated more than mentally ill, Gloucester is an important contrasting figure, whose grief at his betrayal of Edgar mirrors Lear's grief for Cordelia. Gloucester has rejected his loving son in favour of his lying bastard, just as Lear rejected his loving daughter Cordelia in favour of Regan and Goneril who in turn reject his authority. In many ways this change in companions represents a shift in Lear's own self-knowledge. As Edgar identifies 
with the disenfranchised Lear, so too Lear identifies with Edgar, which builds up the impression that Lear has been wronged. Upon meeting poor Tom, Lear asks, "Hast thou given all to thy two daughters? And art thou come to this?" (3.4.49-50) then, "What, has his daughters brought him to this pass? / Couldst thou save nothing? Didst thou give them all?" (3.4.62-3). Lear's self-awareness, when it comes to his outright descent into madness, reveals itself here as a form of utter self-absorption. When Kent suggests that poor Tom "hath no daughters" (3.4.66), Lear responds with an enraged denial, saying, "Death, traitor! nothing could have subdued nature / To such a lowness but his unkind daughters." (3.4.67-8). Unable to see beyond his own anger and suffering, Lear is intent not only on his own diseased mind, but also on projecting the causes of his disease onto others as a sort of diagnosis.

Lear's disease is, at first, characterised by self-absorption, not the profound connection with all humanity which is often thought of when Lear is brought up. Before he meets Edgar, Lear has given the famous speech:

Poor naked wretches, whereso'er you are,

That bide the pelting of this pitiless storm,

How shall your houseless heads and unfed sides,

Your looped and windowed raggedness, defend you

From seasons such as these? O, I have ta'en

Too little care of this! Take physic, pomp;

Expose thyself to feel what wretches feel,

That thou mayst shake the superflux to them,

And show the heavens more just.

Nevertheless, instead of attempting to feel what Edgar feels, Lear attempts to superimpose his own illness onto Edgar. He predicts in his speech that his 'pomp' shall be cured by his exposure to the experience of wretches, but in his responses to Edgar he proves unable to understand a suffering he is not directly exposed to. Lear's firm assertions that poor Tom must have daughters who have driven him into madness shows the narrow focus of Lear's mind at this point. If anything, Lear demonstrates his 'pomp' or egocentricity here, not the working of the 'physic'.

It is evident that Lear's anger and sense of betrayal prevents any sympathetic response to poor Tom. His concern with the disenfranchised in 3.4 has more to do with his own change 
in status. While Lear does recognise his failing as a king, saying, "O, I have ta'en / Too little care of this", his concern seems less linked to sympathy than to the fact that he is beginning to consciously take on the role of the "[p] oor naked wretches". Lear's behavioural developments demonstrate his semi-conscious donning of the role of the literary madman. After scolding Kent for suggesting poor Tom may not be maddened by daughters, Lear asks:

Is it the fashion that discarded fathers

Should have thus little mercy on their flesh?

Judicious punishment! 'twas this flesh begot

Those pelican daughters.

(King Lear 3.4.69-72)

Edgar is feigning madness, and earlier suggested he would follow the model of Bedlam beggars who "[s]trike in their numbed and mortified bare arms / Pins, wooden pricks, nails, sprigs of rosemary;" (2.3.15-6). Lear then takes his behavioural cues from a false madness, which is taking cues from real, non-literary insanity. Attention is drawn to the acting of madness, a minor fracturing of the illusionary world of the play. Shakespeare makes clear that Lear is experiencing a more theatrical form of madness, one in which there is profound wisdom to be gained.

To regard the wisdom as stemming from the disease itself is problematic. Such an interpretation ignores Poor Tom's less literary display of madness which is more or less utterly devoid of reason. In drawing profundity into Lear's speeches, Lear's disease is necessarily divorced from absolute realism. To avoid undermining the realism in Shakespeare's depiction of disease, John Bucknill argues that: "It is only when all the barriers of conventional restraint are broken down, that the native and naked force of the soul displays itself. The display arises from the absence of restraint, and not from the stimulus of disease" (The Mad Folk of Shakespeare 165). In this interpretation, disease does not have the power to make someone more than what they already have the potential to be. Bucknill is arguing that Lear does not become more capable of philosophical thought in his disease, but rather more inclined to it and to voicing his thoughts and emotional turmoil. Bucknill stresses the importance of the development of mental disease in Lear, arguing that he exhibits signs of disease from the beginning of the play ("as we read the play, the mind of Lear is, from the first, in a state of actual unsoundness, or, to speak more precisely, of disease." (Bucknill 177)), and that the emotional disturbance he suffers is as much a part of his disease as his 
complete departure from reason in the later acts (167-9). Early modern ideas about the progression of disease and its beginnings in imbalances of the humours support the idea that Lear is at least somewhat mentally disturbed at the outset of the play. However, while Lear's disease does follow the basic structure for mental illness set out by early modern medicine, Shakespeare was not bound to medical realism. The point of Lear's madness is not its accuracy or what it might suggest about his 'character' before the play begins, but the drama it grants to the profound, wise, foolish, and belated realisations he comes to as a fallen king.

Much of the drama in King Lear is reliant upon the relationship between the mentally ill and society as a whole. Lear is able to inhabit two roles within the body politic of the play simultaneously due to his disease. As a king he is at the pinnacle of the social order, and his power is theoretically absolute. And yet, at the very same time he is a dispossessed madman wandering the countryside - the lowest of the low. Kent, Gloucester, and Cordelia all continue to attend him as his mind gives way, but even then in 4.6 Lear enters alone having become separated from the sane world of the play. Utterly cast out from the centre of the social world, Lear is nonetheless at the centre of the play. His experience of insignificance and insanity has a profound significance for the audience, showing as it does the decay of a man, a mind, and a king.

As the body politic has, for the most part, forgotten him, Lear in his madness remembers the responsibilities of kingship. His earlier protests that he is "[a] man more sinned against than sinning" are placed to the side and he is become the "bare, forked creature" he wondered at. It has often been noted that Shakespeare makes his great revelations and the great realisations of the tragedy in the midst of Lear's madness. One of the truly great realisations he has concerns what may be called the 'myth of kingship'. In 4.6, having lost everything, Lear tells Gloucester:

They flattered me like a dog; and told me I had white hairs in my beard ere the black ones were there. To say 'ay' and 'no' to everything that I said! - 'Ay' and 'no' too was no good divinity. When the rain came to wet me once, and the wind to make me chatter; when the thunder would not peace at my bidding; there I found 'em, there I smelt 'em out. Go to, they are not men o' their words! They told me I was everything; 'tis a lie, I am not agueproof. 
It is in this speech that Lear recognises his own fallibility. Furthermore, he criticises the rhetoric of kingship, which led him to believe he was 'everything'. ${ }^{27}$ Lear's comparison of his treatment to that of a dog reverses wider Renaissance rhetoric which grants the power of a god to a king. This intent is made clear when he counters the flatterers' treatment of him with the argument that "the thunder would not peace at my bidding", referring to the legend of King Canute and the Waves. His suffering, his total fall from power, allows him to finally recognise the natural human limits to which he has always been subject.

Of course, it is a literary form of disease which allows Shakespeare to draw these connections between kingship, power, flattery, and the common human experience. Clearsighted reflection and the realisation of one's own limitations are not commonly connected to mental illness. Rather, Lear's earlier lines, “Look, look, a mouse! Peace, peace; this piece of toasted cheese will do 't. There's my gauntlet; I'll prove it on a giant" (4.6.88-90), give an impression of 'realistic' insanity with their lack of logic or significance. The profound ravings of Lear represent a break from this sort of nonsense into a more literary madness in which there is insight and sense.

Literary disease, then, not only allows Lear to exist in a liminal social position, it also allows him a certain profound clarity. When confronted with Gloucester's blindness, Lear comments on the injustice and immorality of the world:

LEAR What, art mad? A man may see how this world goes with no eyes. Look with thine ears. See how yond justice rails upon yond simple thief. Hark, in thine ear. Change places and, handy-dandy, which is the justice, which is the thief? Thou hast seen a farmer's dog bark at a beggar?

GLOUCESTER Aye, sir.

LEAR And the creature run from the cur? There thou mightst behold the great image of authority: a dog's obeyed in office.

\footnotetext{
${ }^{27}$ Renaissance political treatises not only suggest that a monarch's power is absolute, but also insist that the monarch is invariably right.
} 
His question as to what constitutes authority is well posed. How, without looking, can one tell the difference between a justice and a thief? There is of course the further suggestion that the justice is the thief, and Lear later tells Gloucester, "Plate sin with gold, / And the strong lance of justice hurtless breaks" (4.6.159-60). Lear's ranting highlights the presence of universal immorality and the lack of any universal justice to counter it. His remark that "a dog's obeyed in office" harks back to his line "they flattered me like a dog" (4.6.95), and grants a continuity of image across the speeches, which is demonstrative of his madness's literary nature. The image of a dog as king emphasises not only corruption, but a certain mindlessness in the powerful. "A man may see how this world goes" but until he lost his throne, Lear was, metaphorically speaking, a dog and blind to the injustice and suffering infecting his kingdom.

Grimly enough, the human experience to which Lear anchors himself in his madness is that of disease, which creates something of a problem in how we are to interpret Lear's revelation. When Gloucester asks to kiss Lear's hand in greeting, Lear says, "Let me wipe it first; it smells of mortality" (4.6.131), as if his realised humanity is something which he is ashamed of when confronted once again with his position as a king. As a tragic figure Lear's realisation of both his past station and his current condition creates a profound moment for the play as a whole, and emphasises tragedy inherent in his belated recognition of the faults of his kingdom. From the "[s]tench" and "consumption" (4.6.126) he sees in women, to the "scurvy politician" (4.6.165) the state Lear portrays in his madness is diseased and disordered. Injustice is presented as disorder in his speeches, and the references to disease reinforce the distasteful nature of these truths. Lear comes to recognise his humanity, and the human condition, but his revelations are constrained by his diseased condition, his betrayal, and the genre in which he functions.

The literary or manufactured madness in this play allows Shakespeare scope to discuss sin, injustice, and mortality without coming to any solutions to the issues he raises. Lear has not abdicated the throne and so remains an important legal and religious figurehead throughout his insanity, but devoid of the power and responsibilities of sanity and kingship, he may freely critique the power structure and social order from which he is outcast without consequence. However, unlike Edgar, Lear cannot be reinstated within the social world of the play. His madness, which has allowed him such profound insight into the issues of his state and rule, prohibits his return to kingship. Instead, with the death of Lear, the body politic is given a new head and, as in 2 Henry $I V$, the audience is left with the impression that all is resolved with the heroic ascension of the new king. 


\section{Madness in Twelfth Night}

In Twelfth Night, a play very different in tone, the primary concepts of power, social order, and insanity are woven together in a manner which serves to reinforce ideals of order more than critique them. Unlike King Lear, Twelfth Night does not concern itself much with laws and justice, focusing more on love and intangible class boundaries. The social order of any play world is partially constructed through the individual experiences of disease the characters suffer. In Twelfth Night the noble and elevated primary love story is infected with an equally noble and elevated love sickness, which serves to denote an impenetrable class boundary. Characters such as Viola and Orsino use rhetoric of longing rather than lust to express their love or, rather, the purity of their love. In the opening scene of the play Orsino is characterised as afflicted by lovesickness. Indeed, more trouble is taken to establish him as nobly lovesick, than to denote any other aspect of character. His sighs, his request for, then rejection of, music, his play on the word 'hart', and his rejection of the masculine pursuit of hunting in favour of "sweet beds of flowers" (1.1.39) all serve to paint him as a lovesick lord, but do little else to grant him character. Telling us little about him, Orsino's pining establishes Olivia's name and circumstance and in comparing her to Diana, deifies her. While there is the suggestion of what we might call more base lusts in his comparison of his desires to "fell and cruel hounds" (1.1.21), Orsino's rhetoric is that of Petrarchan love poetry and focuses on the unattainability of Olivia and his personal suffering of unrequited love. The highly literary suffering here is nearly to the opposite of that we see in Lear, the only issue being Orsino's unrequited love. The speeches are borne of the suffering of unrequited love, and discuss such love but, just as in Lear's discussion of injustice, there is no resolution. The scene is centred on a circular argument and progression is impossible without the exterior intervention of Viola.

As one of the major issues of the play as a whole, love is complicated in Twelfth Night. Love is a disease, but also a cure. As a disease it is a time-worn literary motif. ${ }^{28}$ The literary history of lovesickness seems to weigh the whole first scene down. There is no action to this lovesickness, and the only discussion of movement from one condition to another is

\footnotetext{
${ }^{28}$ For background on lovesickness see Peter Toohey's "Love, Lovesickness, and Melancholia” for the classical roots of the medicalization of the condition, and Mary Frances Wack's Lovesickness in the Middle Ages: the Viaticum and its commentaries for an in-depth inquiry into lovesickness.
} 
highly rhetorical. Yet even in Orsino's lack of depth, Shakespeare has managed to make the familiar, high-flown language of love-sickness unsettling. Orsino shapes love as an experience which consumes the whole self and allows for no variation or change:

How will she love when the rich golden shaft

Hath killed the flock of all affections else

That live in her - when liver, brain, and heart,

These sovereign thrones, are all supplied, and filled

Her sweet perfections with one self king!

The underlying sexual connotations in this passage are paralleled and unsettled by the connotations of death. The marriage of these two elements undermines the important part physical desire has to play in most expressions of romantic love. By hiding the suggestion of lust alongside the suggestion of death, Orsino's love is made problematic. By hiding both behind the allusion to Cupid, death is able to take prominence, due to the classical connection this has to the earlier allusion to the myth Diana and Acteon, which created the idea of love hunting to kill "all affections else". The subsequent reference to the sovereign thrones of the body also limits interpretations of this passage as overtly lustful. The liver was deemed the primary seat of lust but, tempered by the heart and brain in this image, Orsino is suggesting a situation where love for him might rule her wholly. So while the romantic love expressed in Orsino's speeches suggests lust at times, it is far from a primary function of his problematic love.

The nature of love and lovesickness is shaped as a concern from the opening of Twelfth Night. Lust is not considered a primary element of love in the heightened rhetoric of the lovers; however, sex was traditionally considered a cure for love sickness (Wack "Lovesickness in Troilus" 56-7). By the early modern period physicians no longer considered lovesickness a serious malady. In 1592 Thomas Lodge has his character Eurimone deliver these mocking lines to her would-be lover:

it is a principle in Phisike, [that] the knowledge of sicknes is to some men the occasion of death: therefore (gentle friend) complayne not of this love sicknes, least in stead of bedding you, we bury you. 
Lodge is writing a comic work here, designed to comment on literary tropes, and is here highlighting the divorce between the real and literary. Eurimone is in no way moved by her would-be lover's 'sickness', and goes so far as to suggest that if he continues complaining she will let him die rather than bed him. Literary lovesickness had developed into a highly formalised set of behaviours by Shakespeare's time and, framed as a disease, it allows potentially dominant characters leeway to claim the role of victim and deny responsibility for their 'lovesick' behaviour (Wack “Lovesickness in Troilus" 58). In Twelfth Night this stylised concept of love sickness is used to mark class boundaries, as only the noble characters are able to correctly display it.

Of course to understand how love sickness is being used in the play, it is important to gain some idea of how love is imagined by the various characters. In Twelfth Night the nature of love itself is presented as ultimately indeterminate from the beginning of the play. Orsino, in the opening speech of the play, says of love: "So full of shapes is fancy / That it alone is high fantastical" (1.1.14-5). Orsino's love, then, is not only immediately connected to indecision but these lines also suggest that love itself is indecisive. The effect of love on disease he imagines is also telling: in the first scene he says, "O, when mine eyes did see Olivia first / Methought she purged the air of pestilence" (1.1.18-9). Later in the play, when Olivia falls in love, she remarks, "how now! Even so quickly may one catch the plague?" (1.5.264-5). The parallel uses of disease metaphors here imply two very different views on love. Orsino presents love as a cure, while Olivia describes it as a sudden and potentially deadly affliction, suggesting that where Orsino finds delight in love, Olivia finds dread. The comparison between the suffering of disease and the suffering of love forges a link between women in the play, and establishes feminine love to be distinct from masculine love. Viola also describes a woman's lovesickness as a form of wasting disease, a "green and yellow melancholy", whilst Sebastian, like Orsino is inclined to frame love as a fantasy, or a dream. Intangible and tangible descriptors create tension between the gender roles, and the language of disease places more visceral suffering on the female characters. Even within the upper class world of the play, lovesickness and the language of disease allows for distinctions to be made between characters who possess the power to act and those who inhabit the passive role in courtship.

The exclusion of poetic and flowery lovesickness from the world below the stairs in Twelfth Night is just as important to our interpretation of the characters who appear in the 
secondary plot as it is to the main plot. The conception of lovesickness as a classist sort of disease is unsurprising given its traditional ties to court culture. The lack of romantic suffering apparent in Malvolio or Sir Andrew is sufficient that we do not consider them actual contenders for Olivia's hand at any point. Maria and Sir Toby weigh Sir Andrew as a suitor for Olivia at the opening of 1.3, wherein he is presented as "a foolish knight that you [Sir Toby] brought in one night to be her wooer" (1.3.12-3) and Maria levels the accusation that he is "drunk nightly" in Sir Toby's company (1.3.30-1). Sir Toby's defence of the man is proved false or at least exaggerated over the course of the play. Placing Sir Andrew as a night figure, engaged in revels, undermines the possibility that an audience would deem him a suitable lover for the noble Olivia. Sir Toby too, for all his initial defence of Sir Andrew's many fine qualities, reveals that he does not take his companion's chances seriously. Commenting on Sir Andrew's hair he says, "it hangs like flax on a distaff, and I hope to see a housewife take thee between her legs and spin it off' (1.3.85-6). Such feminising and bawdy humour cannot co-exist in the upper social strata with lovesickness, which is the currency of 'true' lovers in this play.

Indeed, it is bawdy humour, again, which serves also to keep Malvolio from being taken seriously as a lover. His 'self-love', which is deemed an illness, encourages him to overstep social boundaries. He justifies his fantasy of being "Count Malvolio" (2.5.30), saying to himself, “There is example for't: the Lady of Strachey married the yeoman of the wardrobe" (2.5.34-5). His imaginings are not based in any lovesickness, remaining thoroughly in prose and, moreover, alluding directly to sex and focussing on power. He has, he imagines, "come from a day-bed" where he has "left Olivia sleeping" (2.5.43-4) and he day-dreams of commanding obedience of even Sir Toby. Once more the lack of a particular suffering, a particular literary disease, not only undermines a character as a suitor for Olivia, but also reinforces the idea of his social inferiority. When, after receiving the infamous letter, Malvolio appears before Olivia, his cryptic allusions to the letter baffle Olivia and his behaviour is interpreted as a more dangerous, and certainly not romantic, form of madness. The possibility for a romantic type of madness is given in Olivia's declaration "I am as mad as he, / If sad and merry madness equal be" (3.4.14-5). However Malvolio's reaction to Olivia's concerned "Wilt thou go to bed, Malvolio?" (3.4.37) is so far from appropriate that instead of rising in the social order of the play, his perceived madness has him descend so far as to be at the mercy of the revellers. His line "To bed? 'Ay, sweetheart, and I'll come to thee" "(3.4.38-9) is too blunt, too direct, to be taken as the protestations of a lovesick man. 
In Twelfth Night the issue of mental disease is undeniably more socially complex than in King Lear. Lovesickness plagues the characters in main plot, and in the secondary plot line Malvolio is afflicted by an excess of self-regard, which is termed a sickness within the play. He never enters the complete raving madness of poor Tom or the serious and philosophical madness of Lear; as such insanity would be unsupported within the comedic play world. The more harmless self- love of Malvolio is a social disease. In The Passions of the Minde, Thomas Wright writes of self-love: "she will have gorgeous, and above her state and condition; Insumme from this infected love sprung all the evils, welnie, that pester the world" (24). This specific type of mental disorder suits Malvolio who is trapped between worlds in Twelfth Night. He is quite liminal from the outset, undeniably a servant but aloof in the face of Sir Toby and Viola. He demonstrates a concern for pomp and ceremony which is largely ignored by all the other characters. ${ }^{29}$ For all his concern for the markers of rank, he is also the most determined to advance in rank. Malvolio appears to focus on rank and propriety as a means of wielding power. When he scolds the revellers in 2.3 , he asks, "Is there no respect of place, persons, nor time in you?" (2.3.82-3), but then he comes close to overstepping his bounds, saying:

Sir Toby, I must be round with you. My lady bade me to tell you that though she harbours you as her kinsman she's nothing allied to your disorders. If you can separate yourself and your misdemeanours you are welcome to the house. If not, an it would please you to take leave of her she is very willing to bid you farewell.

While he takes care to refer to his lady by invoking her superior rank, Malvolio clearly relishes being "round" with Sir Toby. Of course, Sir Toby is aware of the hypocrisy evident in Malvolio scolding him for his disrespect of "persons" and confronts him with "Art any more than a steward?" (2.3.102-3). It is Malvolio's hypocrisy concerning social status and respect which triggers the revellers to mock him up as a madman. Furthermore it is

\footnotetext{
${ }^{29}$ Though it must be said that Olivia asks several times after Viola's parentage $(1.5 .133-138 ; 187 ; 247)$ demonstrating a concern with rank. Olivia's worry about Viola's status is easily read as an indication of her growing infatuation meeting a natural concern for propriety. Of course, this also demonstrates that Malvolio does not have a chance of wooing her.
} 
Malvolio's desire to escape the conditions of his social status which leaves him open and gullible to the sort of attack Maria plans.

In terms of disease in the play, Malvolio suffers conditionally. He is, in Olivia's words, "sick of self-love" (1.5.77), and his private fantasising appears as a clear symptom of this sickness. Self-love, though, appears to function as a sort of lovesickness. So, while Malvolio is overtaken by his imaginings, they are not regarded as a manifestation of a disease which makes him a danger to others. The fantasising does serve to reinforce the idea of Malvolio possessing an innate imbalance in character, while we also engage with him on a level where we understand he is not mad. His delusional behaviour is such that he acts out a scene which is not real in 2.5 , having been completely carried away by his imagination. While this may be taken as a sign of insanity, the audience is more likely to consider it a daydream than a complete break from reality.

The madness which is to overtake the subplot and the stern Malvolio is foreshadowed in the opening of his censorship of the revellers. When he asks: "My masters, are you mad? (2.3.78), little does he know that that question will return to plague him, as Maria places it at the centre of her practical joke. The practical joke itself has madness at the heart of it, and is based on the disease Malvolio is infected with from the first - his self-love. To add a further layer, Malvolio is condemned for his display of lovesickness, a disease which plagues the majority of characters tied up in the primary plotline, but which is beyond his social scope. Shakespeare toys with traditional conceptions of madness in this prank, putting forth questions for his audience to consider. Can cures for madness cause madness? Can a person be driven to madness? And most importantly: How do we know if someone is mad? Malvolio is fooled, but it is difficult to fault him for falling into the trap set by Maria. Given Maria tells Sir Toby that "on a forgotten matter we can barely tell our hands apart", mistaking the origin of the letter is the default (even so, Malvolio takes time to note the use of Olivia's seal). His attention to detail cannot be faulted, nor can his belief that it is he for whom the letter is intended. Maria tells her fellow conspirators (with whom we the audience identify - at least until Malvolio’s imprisonment):

I will drop in his way some obscure epistles of love, wherein by the colour of his beard, the shape of his leg, the manner of his gait, the expressure of his eye, forehead, and complexion, he shall find himself most feelingly personated 
The letter is intended for Malvolio. Indeed, while his reaction to the letter is wholeheartedly comic, the perfection of the trap adds to the sense of unease we feel as the comedy descends into cruelty. While we understand from his behaviour on his walk - with the aid of such commentary as Maria's line: "Malvolio's coming down this walk. He has been yonder i'the sun practising behaviour to his own shadow this past half-hour." (2.5.13-15) - that Malvolio does desire the power and pomp of social elevation, the prank does not rely wholly on his narcissism to work. Instead the prank feeds Malvolio's self-love and convinces him to make his private imaginings public action. The attitudes he takes on in his private daydreams are put on in his day to day life and, at Maria's suggestion, deemed mad.

Malvolio's actions never truly suggest a break from what he considers to be reality, but his behaviour upon finding the letter ultimately assures the audience of his social delusions. The letter is addressed to "the unknown beloved"" (2.5.82) and yet he does not hesitate to open it. Beginning to read he almost instantly sees how the verse could fit to his name: “'No man must know.' What follows? The numbers altered. 'No man must know.' If this should be thee, Malvolio?" (2.5.91-2). His interpretation at this point is biased, but not nearly the culmination of his self-delusion. Malvolio continues his interpretation of the letter's contents:

'I may command where I adore.' Why, she may command me. I serve her, she is my lady. Why this is evident to any formal capacity. There is no obstruction in this. And the end - what should that alphabetical position portend? If I could make that resemble something in me. Softly - 'M.O.A.I.' . . 'M.' Malvolio - 'M' why, that begins my name. . . ' $M$.' But then there is no consonancy in the sequel. That suffers under probation. 'A' should follow, but ' $\mathrm{O}$ ' does. . . . And then 'I' comes behind. . . 'M.O.A.I.' This simulation is not as the former; and yet to crush this a little, it would bow to me, for every one of these letters are in my name.

$$
\text { (2.5.104-24) }
$$

As soon as he expresses a desire to make the letter's contents resemble his own person, Malvolio has stepped beyond reason. His determination to "crush" the letter's letters a little to have them fit his name is sufficient to confirm Olivia's suggestion that he is sick of selflove, but at the same time the audience knows the letter was left for him; the letters do indicate his name. Maria's recognition of Malvolio's delusions allows her to take advantage 
of him, to have him unwittingly behave as if he suffered from a much more serious condition. Malvolio's initial slight imbalance leaves him open to exploitation in a manner which seems surprisingly probable.

When he appears to Olivia dressed as the letter suggested, Malvolio fully expects to be received as a lover not a madman. However, Maria has already suggested he is insane, already undermining his advances. Nonetheless Malvolio's expression of lovesickness is greatly divorced from the Petrarchan and noble ideals. Not only does he misinterpret Olivia's query, "Wilt thou go to bed, Malvolio?" (3.4.27) as a sexual overture, but he also fails to be at all poetic in his approach. The closest he comes is when he deigns to answer Maria, saying: "nightingales answer daws" (3.4.33), but it is not Olivia who he compares to a nightingale; rather, it is himself. Lacking the ability to show noble lovesickness, Malvolio not only fails to climb the social ladder, but he also finds himself falling to the bottom of the social order. Olivia declares him to be suffering from a "very midsummer madness" (3.4.52), and instructs Maria:

Good Maria, let this fellow be looked to. Where's my cousin Toby? Let some of my people have a special care of him, I would not have him miscarry for the half of my dowry.

While Malvolio is not cast out of the household like the madmen of King Lear, he has lost his social standing in that he is under the command of others, and no longer in a position to command. Madness is to be treated within the household in Twelfth Night, but the presumed loss of mental control in Malvolio is responded to by the stripping away of his social power.

Malvolio is left at the mercy of the household he once ruled, just as Lear was at the mercy of his daughters. The entire movement of the scene follows Sir Toby's pronouncement "Why, thou hast put him in such a dream that when the image of it leaves him, he must run mad" (2.5.168-9). The dream, Olivia, leaves the stage, and Malvolio is left to the comic nightmare of Sit Toby's taunts. While the prank was conceived as a 'cure' for Malvolio's 'sickness', in action it becomes a sort of cruel bear-baiting by the revellers. Maria tells her companions it will be "[s]port royal, I warrant you. I know my physic will work with him" (2.3.152-3). In response to his condemnation of Fabian's bear baiting, Malvolio has been put into the position of the bear. The bear baiting motif is accompanied by the inclusion of both medical and religious superstition, and all serve to frame Malvolio's behaviour as mad. 
For all their identification of the symptoms of Malvolio's madness, it is the revellers in this scene who appear mad. In their antic frenzy they cannot decide whether Malvolio suffers from madness or possession. Maria, mocking Malvolio’s haughty tone, says, "Lo, how hollow the fiend speaks within him" (3.4.84) but ten lines later Fabian tells her to "Carry his water to th'wise woman" (3.4.94), suggesting that the madness is medical. The potential physical comedy of the line is apparently curbed by Maria's reply: "Marry, and it shall be done tomorrow morning, if I live" (3.4.95). Fabian chasing Malvolio about the stage with a jar for him to pee into is certainly worth a break from the religious rhetoric. Indeed, it is comedy, not accuracy or sense, for which this scene strives. As I have discussed earlier, literary madness has great theatrical potential. Of the four people onstage, the audience is not expected to believe a single one mad. The antic vengeance of the revellers and Malvolio's exaggerated gravitas allow for a comedic and thrilling display, but the dark satire of the scene does also show the vulnerability of the purported madman, and the scant evidence needed to condemn him.

The antic baiting of Malvolio is turned into a trial after his exit from the scene. Evidence has been given in the interpretations of his behaviour (though no urine collected), and the revellers pass judgement on Malvolio after his exit:

SIR TOBY His very genius has taken the infection of the device, man.

MARIA Nay, pursue him now, lest the device take air and taint.

FABIAN Why, we shall make him mad indeed.

MARIA The house will be the quieter.

SIR TOBY Come we'll have him in a dark room and bound. My niece is already in the belief that he's mad. We may carry it thus for our pleasure and his penance till our very pastime, tired out of breath, prompt us to have mercy on him, at which time we will bring the device to the bar and crown thee for a finder of madmen.

Sir Toby is determined to punish Malvolio, and imprison him, not because he believes the man has gone mad, but because the evidence necessary to condemn him is there. Lear's 
insight regarding vulnerability of the disenfranchised to injustice seems to have echoes here. Stripped of his social power and position, Malvolio has no defence against Sir Toby.

The resolution of Sir Toby to continue his exploitation of Malvolio "for our pleasure and his penance" is the point at which the prank begins to sour for the audience. Where first the minor self-delusions of Malvolio were framed in a way to make the audience dislike him, the threat of more a serious 'total' madness brings him back into the audience's sympathies. Even to an early modern audience the treatment of Malvolio would have been recognised as unkind and outdated. The dark room was a medieval method for treating madness and the practice was dying out in Shakespeare's time (Hoeniger 191). Fitting in neatly with the superstitions and outdated urine tests, Malvolio's imprisonment is intended to be seen as knavery and injustice by the audience.

In recognising the injustice of Malvolio's treatment, the audience is necessarily drawn to question its humanity. In King Lear madness is partly used to draw Lear down from the divine heights of kingship to a point where he can relate to the common human experience. In Twelfth Night this decline in state from divine to human to sub-human is taken too far for comfort. Malvolio has not only his authority removed by the prank, but also any power of self-determination. Having been imprisoned, Malvolio is accused of being possessed by a "hyperbolical fiend" (4.2.22) by Feste. With his voice attributed to an inhuman agent Malvolio has the impossible task to prove a negative - that he is not mad - to regain his voice, his freedom, and his social status. Malvolio repeatedly attempts to assert his sanity by way of negatives. He tells Feste, "do not think I am mad" (4.2.26), "I am not mad" (4.2.35), and "I am no more mad than you are" (4.2.42) but this is to no avail within the play. For the audience the comedy of the prank is dried up. Where before Malvolio unwittingly played the role of the madman, now there is no play, only helplessness and begging. Even when slaves like Thersites are comically beaten in Elizabethan plays they retain their voices to rail at their masters. The utter removal of Malvolio's voice and power results in him falling to a subhuman position within the play yet, at the same time, the audience is necessarily aware of both his humanity and his relative sanity.

The uncomfortable position of the audience is alleviated somewhat by Sir Toby's decision to end the prank. Sir Toby clearly is aware of his wrongdoing when he says,

I would we were well rid of this knavery. If he may be conveniently delivered, I would he were, for I am now so far in offense with my niece that I cannot pursue with any safety this sport to the upshot. 
(4.2.60-3).

Sir Toby seems to be aware of the cruelty of the prank as he terms it 'knavery', and yet there is a sort of reluctance to this conclusion. Sir Toby encourages the employment of Sir Topas for the continued torment of Malvolio before calling an end to proceedings, and the sinister implications of the 'upshot' he refers to are clear, the intended end of the trick would have been the complete decay of Malvolio's mind. Malvolio has been reluctantly granted a return to humanity within the play world, but even this is mismanaged. Responsibility is given over to Feste, the fool, whose mental state is questionable and who is has cause to dislike Malvolio. ${ }^{30}$ Feste does manage to bring comedy back into this plot when he mocks Malvolio's reliance on him as a frame of reference "you are mad indeed, if you be no better in your wits than a fool" (4.2.83-4). The clear contrast he makes between his allowed madness and Malvolio's contraband sanity serves to emphasise once more the issue of social order. In a fool madness is allowed, in a steward it is condemned.

Without the disturbing secondary plot, Twelfth Night could end as a straightforward romantic comedy with the proposed marriages of Orsino and Viola, and Olivia and Sebastian. However, the maltreatment and dehumanisation of Malvolio cannot be ignored, and with the concluding reveal of the reveller's antics, the sub-plot is reshaped from a comic prank into a revenge narrative. Fabian attempts to frame the torment of Malvolio as justice, saying, "If that the injuries be justly weighed" all may "rather pluck on laughter than revenge" (5.1.356; 355). Feste undermines the idea of justice when he ends his summary with "and thus the whirligig of time brings in his revenges" (5.1.364). The revellers were not truly seeking justice; their intent was revenge. Malvolio in turn twists the end of the romantic comedy into the shape of the beginning of a revenge play. His dramatic declaration: "I'll be revenged on the whole pack of you" (5.1.365), disturbs the conclusion of the play and embitters the happy ending.

The personal and often horrifying experiences of mental disease we are presented with in King Lear and Twelfth Night primarily serve to emphasise the commonality of man to the audience. In both plays insanity causes a loss of social status. In King Lear the king removes himself from his place at the head of the body politic, unburdening himself of his responsibilities and also his almost divine power. His choler and madness has him cut all ties to his kingship and he is forced to confront his innate humanity. In a different spectacle

\footnotetext{
${ }^{30}$ See Robert H. Bell's Shakespeare's Great Stage of Fools for more on the mental state of fools in Shakespeare's plays.
} 
altogether, Malvolio in Twelfth Night is fooled into acting mad, and his mad action results in the revellers being able to remove from him his humanity. Demonised and imprisoned, Malvolio's 'madness' is equally as harsh as Lear's, and forces the audience to recognise his humanity and the injustice of the revellers' revenge.

The literary nature of madness within these plays allows for the clear presentation of issues of class and justice. The levels of literary madness vary widely, from the gibbering, and possibly more 'real' madness of Poor Tom to the languishing lovesickness of Orsino. In all cases, to seek to diagnose or trace the medical lines of these types of madness would be misguided. Much more important is the social order which Shakespeare uses these manufactured presentations of madness to construct and illustrate. Lear's transitory and transgressive social state within the play presents questions of right and power to the audience. Malvolio's inept lovesickness and subsequent torment provides an unsettling condemnation of social movement and ambition. The theatrical nature of madness allows the theatre of the courtroom to be parodied and Shakespeare uses these opportunities to draw questions of injustice into both plays. In Lear the issues of class and social discrimination in law which are raised cannot be resolved by the insane Lear, and in Twelfth Night the 'justice' of Malvolio's mistreatment is revealed to be no more substantial than his 'madness'. Neither play is able to come to a satisfactory conclusion about injustice, but that is not the purpose of madness. Madness functions as a means to draw attention to social issues; its inability to provide answers does not lessen the significance of this role. 


\section{Conclusion}

Disease functions in a variety of ways throughout the four plays I have looked at in this thesis. It is a primary means of problematizing political structures within the frame of the body politic; it is used to condemn socially problematic behaviours, to reinforce class structures, and to create profundity, pathos, and passion. Characters are given depth through their very human suffering of disease, but we must remember that disease within the plays is a highly literary construction. The suffering of specific diseases and the suffering of particular characters function as signposts for an audience or reader, allowing them to grasp at the wider themes and issues presented within the play.

In consideration of the body politic and contagion, it is essential that we as critics remember that the body and disease were thought of in a very different way in the early modern period. The concern we have today for external causes of disease was limited in Renaissance philosophies. The early modern understanding of disease was based on texts and ideas which had existed for over a thousand years. These basic principles of medicine, touching as they did upon morality and macrocosmic ideas such as social structure, had already found their way into discourses of state and society. The four humours were a touchstone of common knowledge and, more importantly, of common experience, and by this point had infected literature for centuries.

An internal conception of disease and its causes allowed for an entirely different rhetorical use of disease. Disease appears to have functioned as a literary motif, and elaborate metaphor, used for characterisation and thematic discourse. The versatility of disease in Shakespeare is largely a result of the time period in which the literature originates. In using disease theories, Shakespeare is not thinking outside the box, but he is making very effective use of what is inside.

To Shakespeare's original audience the inclusion of disease and illness, the inclusion of such an inescapable element of mortality, would surely have bridged the gap between the onstage fiction and the reality in which they lived. Illness onstage would have brought, and does still bring, the characters onstage closer to the audience. The impression of realism which disease brings to these plays is not the sole function of disease, as I have proved over the course of this thesis. Instead references to illness form an integral part of the literary construction of the state and social order, of morality and commerce, and condemn social mobility over the course of the plays. The functions of disease I have discussed constitute the 
most significant within the four plays I focus on, and serve to reflect the purpose behind Shakespeare's inclusion of disease and disease metaphor across his canon. 


\section{Works Cited}

\section{Primary Sources}

Aristotle. Aristotles Politiques, or Discourses of Government. Trans. Loys Le Roy, London, 1598. Web: EEBO.

Barnes, Barnabe. Foure Bookes of Offices Enabling Privat Persons for the Speciall Seruice of all Good Princes and Policies. London, 1606. Web: EEBO.

Bartholomaeus, Anglicus. Batman uppon Bartholome his booke De Proprietatibus Rerum, Newly Corrected, Enlarged and Amended. Ed. Batman. London, 1582. Web: EEBO.

Bodin, Jean. The six bookes of a common-weale. London, 1606. Web: EEBO.

Bright, Timothie. A treatise of melancholie. London, 1586. Web: EEBO.

Bullien, William. The Government of Health. London, 1595. Web: EEBO.

De Malynes, Gerrard. A Treatise of the Canker of Englands Common Wealth. London, 1601. Web: EEBO.

Elizabeth I. Orders, thought meete by Her Maiestie, and her Priuie Counsell to be executed throughout the counties of this realme, in such townes, villages, and other places, as are, or may be hereafter infected with the plague, for the stay of further increase of the same... London, 1593. Web: EEBO.

Galen. Certaine vvorkes of Galens, called Methodus medendi with a briefe declaration of the worthie art of medicine, the office of a chirurgion, and an epitome of the third booke of Galen, of naturall faculties: all translated into English, by Thomas Gale Maister in Chirurgerie. London, 1586. Web: EEBO.

Hall, John. A most excellent and learned vvoorke of chirurgerie, called Chirurgia parua Lanfranci Lanfranke of Mylayne his briefe. London, 1565. Web: EEBO.

The Holie Bible. London, 1568. Web.

Learned Phisition. Present Remedies against the Plague. London, 1594. Web: EEBO.

Lodge, Thomas. A treatise of the plague. London, 1603. Web: EEBO.

Lodge, Thomas. Euphues Shadow. London, 1592. Web: EEBO.

Newton, Thomas. The Touchstone of Complexions... first written in Latine, by Leuine Lemnie; and now Englished by Thomas Newton. London, 1576. Web: EEBO.

Plowden, Edmund. The commentaries, or reports of Edmund Plowden, Of the MiddleTemple, Esq; An Apprentice of the Common Law, containing divers cases upon 
matters of law, argued and adjudged in the several Reigns of King Edward VI. Queen Mary, King and Queen Philip and Mary, and Queen Elizabeth. London, 1761.

Web: EEBO.

Shakespeare, William. The Norton Shakespeare. 1557-1613. Ed. Stephen Greenblatt, et al. $2^{\text {nd }}$ ed. New York: W. W. Norton \& Company, 2008. Print.

Talpin, Jean. A Forme of Christian Pollicie. London, 1574. Web: EEBO.

Theophrastus. On Moral Characters. London, 1714. Web.

Vitruvius. Vitruvius: The Ten Books on Architecture. Ed. Morris Hicky Morgan Cambridge: Harvard University Press; London: Humphrey Milford; Oxford University Press, 1914. Print.

Webster, John. The Duchess of Malfi. Nicholas Okes, 1623. Ed. Elizabeth M. Brennan, London: Ernest Benn Ltd., 1964. Print.

Wright, Thomas. The Passions of the Minde. London, 1601. Web: EEBO. 


\section{Secondary Sources}

Bell, Robert H. Shakespeare's Great Stage of Fools. New York: Palgrave MacMillan, 2011. Print.

Belling, Catherine. "Infectious Rape, Therapeutic Revenge: Bloodletting and the Health of Rome's Body," Moss and Peterson 113-132. Print.

Bertram, Benjamin. "Falstaff's Body, the Body Politic, and the Body of Trade," Exemplaria 21.3 (2009): 296-318. Print.

Bucknill, John Charles. The Mad Folk of Shakespeare: Psychological Essays. $2^{\text {nd }}$ ed. 1867. New York: Burt Franklin, 1969. Print.

- $\quad$ The Medical Knowledge of Shakespeare. London: Longman \& Co., 1860. Print.

- The Psychology of Shakespeare. 1859. New York: AMS Press, 1970. Print.

Clark, Sir George. A History of the Royal College of Physicians of London: Volume One. Oxford: Clarendon Press, 1964. Print.

Colman, E. A. M. Dramatic use of bawdy in Shakespeare. New Jersey: Prentice Hall Press, 1976. Print.

Ellis, Anthony. Old Age, Masculinity, and Early Modern Drama: Comic Elders on the Italian and Shakespearean Stage. Surrey: Ashgate, 2009. Print.

Elton, G. R. England under the Tudors. $2^{\text {nd }}$. Ed. London: Methuen \& Co., 1974. Print.

Evans, Meredith. "Rumor, the Breath of Kings, and the Body of Law in 2 Henry IV'. Shakespeare Quarterly 60.1 (2009) 1-24. Web.

Fabricius, Johannes. Syphilis in Shakespeare's England. England: Jessica Kingsley, 1994. Print.

Farrell, Kirby. Play, Death, and Heroism in Shakespeare. London: University of North Carolina Press, 1989. Print.

Fitzpatrick, Joan. Food in Shakespeare: Early Modern Dietaries and the Plays. Surrey: Ashgate, 2007. Print.

Gilman, Sander L. Disease and Representation: Images of Illness from Madness to AIDS. Ithaca and London: Cornell University Press, 1988. Print.

Greenblatt, Stephen. "The Eating of the Soul.” Representations 48.1 (1994): 97-116. Web.

Hale, David George. The Body Politic: A Political Metaphor in Renaissance English Literature. Netherlands: Mouton \& Co., 1971. Print. 
- “Coriolanus: The Death of a Political Metaphor,” Shakespeare Quarterly. 22.3 (1971): 197-202. Print.

Harris, Jonathan Gil. Foreign Bodies and the Body Politic: Discourses of Social Pathology in Early Modern England. Cambridge: Cambridge University Press, 1998. Print.

- “"Some love that drew him oft from home": Syphilis and International Commerce in The Comedy of Errors," Moss and Peterson 69-92. Print.

Hoeniger, F. David. Medicine and Shakespeare in the English Renaissance. London:

Associated University Presses, 1992. Print.

Iyengar, Sujata. Shakespeare’s Medical Language: A Dictionary. London: Bloomsbury, 2011. Print.

Kail, Aubrey C. The Medical Mind of Shakespeare. New South Wales: Williams \& Wilkins, 1986. Print.

Kantorowicz, Ernst, H. The King's Two Bodies: A Study in Mediaeval Political Theology.

New Jersey: Princeton University Press, 1957. Print.

Lemonnier-Texier, Delphine. "The Analogy of the Body Politic in Shakespeare's Coriolanus: From the Organic Metaphor of Society to the Monstrous Body of the Multitude." Moreana 44.168-170 (2007): 107-31. Web.

MacGregor, Neil. Shakespeare's Restless World. London: Allen Lane, 2012. Print.

Margolies, David. Shakespeare's Irrational Endings: The Problem Plays. New York: Palgrave Macmillan, 2012. Print.

Moss, Stephanie and Kaara L. Peterson Eds. Disease, Diagnosis, and Cure on the Early Modern Stage. Surrey: Ashgate, 2004. Print.

Munson, Rebecca. ""The Marks of Sovereignty": The Division of the Kingdom and the Division of the Mind in King Lear" Pacific Coast Philology 46.1 (2011): 13-27. Web. Paster, Gail Kern. Humouring the Body: Emotions and the Shakespearean Stage. Chicago: University of Chicago Press, 2004. Print.

Peterson, Kaara L. "Historica Passio: Early Modern Medicine, King Lear, and Editorial Practice” Shakespeare Quarterly 57.1 (2006): 1-22. Print.

Phillips, James Emerson Jr. State in Shakespeare's Greek and Roman Plays. New York: Octagon Books, 1972. Print.

Rose, Jacqueline. "Kingship and Counsel in Early Modern England.” The Historical Journal 54.1 (2011): 47-71. Web.

Simpson, R. R. Shakespeare and Medicine. Edinburgh and London: E. \& S. Livingstone, 1959. Print. 
Somerville, H. Madness in Shakespearian Tragedy. Edinburgh: The Riverside Press, 1929. Print.

Sontag, Susan. Illness as a Metaphor. New York: Farrar, Straus and Giroux, 1978. Print.

Toohey, Peter. "Love, Lovesickness, and Melancholia." Illinois Classical Studies 17.2 (1992): 265-286. Print.

Wack, Mary Frances. Lovesickness in the Middle Ages: the Viaticum and its commentaries. Philadelphia: University of Pennsylvania Press, 1990. Print.

- "Lovesickness in "Troilus."” Pacific Coast Philology 19.1/2 (1984): 55-61. Web. 